\title{
Effects of oligomer toxicity, fibril toxicity and fibril spreading in synucleinopathies
}

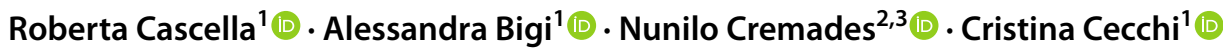

Received: 7 December 2021 / Revised: 17 January 2022 / Accepted: 22 January 2022 / Published online: 4 March 2022

(c) The Author(s) 2022, corrected publication 2022

\begin{abstract}
Protein misfolding is a general hallmark of protein deposition diseases, such as Alzheimer's disease or Parkinson's disease, in which different types of aggregated species (oligomers, protofibrils and fibrils) are generated by the cells. Despite widespread interest, the relationship between oligomers and fibrils in the aggregation process and spreading remains elusive. A large variety of experimental evidences supported the idea that soluble oligomeric species of different proteins might be more toxic than the larger fibrillar forms. Furthermore, the lack of correlation between the presence of the typical pathological inclusions and disease sustained this debate. However, recent data show that the $\beta$-sheet core of the $\alpha$-Synuclein $(\alpha$ Syn) fibrils is unable to establish persistent interactions with the lipid bilayers, but they can release oligomeric species responsible for an immediate dysfunction of the recipient neurons. Reversibly, such oligomeric species could also contribute to pathogenesis via neuron-to-neuron spreading by their direct cell-to-cell transfer or by generating new fibrils, following their neuronal uptake. In this Review, we discuss the various mechanisms of cellular dysfunction caused by $\alpha$ Syn, including oligomer toxicity, fibril toxicity and fibril spreading.
\end{abstract}

Keywords $\alpha$-Synuclein · Parkinson's disease · Protein misfolding · Protein aggregation · Amyloid · Toxic oligomers · Lewy bodies $\cdot$ Prion-like $\cdot$ Neurodegeneration $\cdot$ Protein self-assembly

\section{Introduction}

In protein deposition diseases, such as Alzheimer's disease (AD) or Parkinson's disease (PD), different types of aggregated species (oligomers, protofibrils and fibrils) are formed during the process of protein aggregation. Some of these conformers can be toxic to cells/tissues/organs. Numerous experimental studies in cell and animal models of disease [1-4] supported the idea that soluble oligomeric species of

Roberta Cascella and Alessandra Bigi contributed equally to the work.

Cristina Cecchi

cristina.cecchi@unifi.it

1 Department of Experimental and Clinical Biomedical Sciences, Section of Biochemistry, University of Florence, 50134 Florence, Italy

2 Institute for Biocomputation and Physics of Complex Systems (BIFI), University of Zaragoza, 50018 Zaragoza, Spain

3 Department of Biochemistry and Molecular and Cell Biology, University of Zaragoza, 50018 Zaragoza, Spain different proteins might be more toxic than the larger, fibrillar forms. Furthermore, the lack of correlation between the presence of the pathological hallmark inclusions and disease sustained this issue. Indeed, amyloid-beta plaques and Lewy bodies (LBs) are often found in the brains of individuals without evident signs of AD or PD, respectively. Large fibrillar aggregates are typically harmless for neuronal cells, and the formation of plaques or large aggregated bodies have been suggested to be beneficial once the aggregation process has been triggered [5]. However, we still lack definitive evidence on the nature of the toxic species, mostly due to our failure to detect and define the various protein aggregates.

Synucleinopathies is the general term given to a group of neurodegenerative disorders characterized by fibrillar aggregates of $\alpha$-Synuclein ( $\alpha$ Syn) protein in the cytoplasm of neurons and glia. These disorders include PD, dementia with LBs (DLB), multiple system atrophy (MSA) and pure autonomic failure (PAF) [6]. Glial $\alpha$ Syn filamentous deposits are prominent in MSA and neuronal $\alpha$ Syn inclusions are found in PD, DLB and PAF. Usually, synucleinopathies are clinically characterized by slowness of movement, coordination 
difficulties or mild cognitive impairment, depending on the distribution of the lesions.

The abnormal processing of the 140 residue protein $\alpha$ Syn plays a key role in the pathogenesis of synucleinopathies [7]. Indeed, the cytoplasmic deposition of amyloid-like aggregates of insoluble $\alpha$ Syn causes the degeneration of key areas of the brain involved in the control of movement or cognition. Under physiological conditions, $\alpha$ Syn functions in its native conformation as a soluble monomer and account for $1 \%$ of total central nervous system (CNS) proteins. However, monomeric $\alpha$ Syn is dynamic and can access a large variety of assembly states [8,9], generating oligomeric and fibrillar species that differ in structure, size and morphology because of its high structural plasticity. Depending on assembly conditions, these states can interconvert over different timescales.

Despite widespread interest, the relationship between $\alpha$ Syn oligomers and fibrils in the aggregation process and spreading remains to be clarified. A wide range of studies clearly suggest that $\alpha$ Syn prefibrillar oligomers, formed at the early stages of the aggregation process, are highly toxic to neuronal cells and play a crucial role in the pathogenesis of synucleinopathies, causing dysfunction in neurotransmitter release, cellular oxidative stress, energy depletion and other pathogenetic pathways ultimately leading to neuronal death [10-12]. Studies in PD-related animal models and post-mortem patient material demonstrate that soluble oligomers and protofibrils of $\alpha$ Syn can accumulate in synapses and axons prior to the onset of disease symptoms. However, some researchers found that $\alpha$ Syn fibrils, which are the most thermodynamically favoured species, are also toxic themselves as contribute to the propagation of the disease [13-17]. Thus, a better understanding of the relative contribution of each stage underlying neuronal dysfunction and neurodegeneration in cellular and animal models may support the development of new therapeutic strategies towards the treatment of synucleinopathies. In this Review, we discuss the various mechanisms of cellular dysfunction caused by $\alpha$ Syn, including oligomer toxicity, fibril toxicity and fibril spreading.

\section{Oligomer toxicity}

\section{Myriad of structural types of oligomers}

The term "oligomer" is widely used to describe aggregated $\alpha$ Syn, although the distinction between oligomeric and fibrillar species needs to be established, with a more appropriate concretion of the properties that need to fulfil an aggregate to be ascribed as either an oligomer or a short fibril. We propose size in combination with the $\beta$-sheet content as two of the most critical parameters to distinguish between these two types of aggregated species, with the oligomers displaying a significantly reduced $\beta$-sheet content as compared to that of their fibrillar counterparts. It is important to note that $\alpha$ Syn has been proposed to form also $\alpha$-helical tetramers [18] and higher orders oligomers, mostly upon association with membrane vesicles [19], as functional forms of the protein associated with vesicle fusion in synapsis [20]. These helical oligomeric forms have been, however, reported to be resistant to aggregation [18] and are, thus, considered functional oligomers. Pathological oligomers are associated with the amyloid aggregation process of the protein, and the term "oligomer" in such process encompasses a myriad of species with different sizes, ranging from dimers to high molecular weight species, and with varying degrees of $\beta$-sheet contents, from fully disordered structures to oligomers with a significant $\beta$-sheet core that starts to resemble that of the fibrils.

There are no current effective methods to detect $\alpha$ Syn oligomeric species in situ, and, consequently, the vast majority of studies that try to elucidate the role of these species in disease have utilised in vitro formed oligomers, which have provided important information on the possible mechanisms and structural features determinant for toxicity in these species, as explained latter in more detail. However, it is crucial that new methods are developed in order to detect specifically these species in vivo and in-patient tissues if we aim to uncover their pathogenic effects. In this context, oligomer conformation-specific antibodies have been used to identify oligomeric species in cells (as examples see [21-23]. Unfortunately, the molecular properties associated with oligomer-specific antibodies are not well understood, and most of them show cross-reactivity between different protein species [24] and among oligomers from different amyloidogenic proteins and peptides [22], as well as other non-amyloidogenic proteins [25]. Alternatively, other groups have combined the use of an antibody against a specific epitope in the sequence of $\alpha \mathrm{Syn}$, which would recognise all forms of the protein, from the monomeric protein to the fibrillar forms, with a strong proteinase $\mathrm{K}$ (PK) treatment of the biological sample in what it has been referred to as PK paraffin-embedded tissue blot (PK-PET blot) [26]. The PK treatment guarantees that only PK-resistant protein forms are detected by the antibody, being the mature fibrillar $\alpha$ Syn, thus, the most likely species detected by this method. A different strategy, this time based on the proximity ligation assay (PLA) methodology, was developed by the AlegreAbarrategui group [27], in which the same antibody that recognises $\alpha$ Syn (syn211) is conjugated to a short oligonucleotide. When two conjugated antibodies are in proximity, when bound to an $\alpha$ Syn oligomer or fibril, the oligos become ligated, acting as a primer for DNA polymerase to generate concatemeric sequences through a rolling-circle amplification process using complementary fluorescently 
labelled oligos. This method allows up to 1000 -fold amplified signal that is tethered to the protein complex. Using this approach, the authors described the presence of abundant oligomers diffusely located around the LBs in the medulla and cingulate cortex, which colocalised with pathology in PD post-mortem brain tissue. However, again, this method is not generally able to discriminate between oligomers and fibrils, presenting only a two-fold higher signal for the oligomers analysed, with respect to fibrils, according to the authors [27]. Other methods to ascribe biological effects to oligomeric $\alpha$ Syn species have used cells expressing nonnatural $\alpha$ Syn variants bearing specific single-point mutations designed to accumulate oligomeric species distinct to the fibrillar forms [4] or $\alpha$ Syn bimolecular fluorescence constructs that form oligomers [28]. Overall, these studies show that overexpression of oligomer-prone $\alpha$ Syn variants induces neurodegeneration in the substantia nigra pars compacta of rats [4, 29], while fibrillation-prone variants did not display toxicity [4]. While these studies are essential to understand the nature of the toxic species and their roles in disease, they are still unable to provide detailed structural information of these species, which hampers the establishment of structure-toxicity relationships and, therefore, the rational design of molecules capable of preventing or reverting their pathological effects.

In vitro, two main structural subgroups of oligomers have been reported to be formed during fibril formation: a subgroup of primarily disordered oligomers that are initially formed and a subgroup of more compact, stable and proteinase $\mathrm{K}$ resistant oligomers with partial $\beta$-sheet structure [12, $30]$. By the use of single-molecule experiments, we demonstrated that the main mechanism of fibril formation by $\alpha$ Syn under the most commonly used in vitro conditions follow a nucleation-conversion-polymerization kinetic model [12]. In this model, monomers initially establish the first contacts, typically when the monomeric protein is adsorbed into a hydrophobic/hydrophilic interface (heterogeneous nucleation), forming the early, primarily disordered oligomers, which then suffer a slow structural conversion into oligomers containing $\beta$-sheet structure, which further elongate, increasing their $\beta$-sheet content, until they rich the fully formed fibrillar structure [30]. The increase in $\beta$-sheet structure in these prefibrillar oligomers is likely to be concomitant with an increase in their ability to recruit monomeric protein and grow in size (elongation). The small fibrillar species then generated represent the active nuclei for elongation and multiplication through secondary processes, such as secondary nucleation and fragmentation, speeding up fibril formation exponentially [31,32].

Interestingly, Gosh et al. [33] have proposed that $\alpha$ Syn forms a helix-rich oligomeric intermediate during fibril formation, which can populate ca. $50 \%$ of the protein species at the middle point of reaction and, when isolated, can seed the formation of fibrils. In contrast, under similar in vitro conditions (in the absence of lipid vesicles or surfactant molecules), other studies only report the population of very low concentrations of oligomers, in some cases distinguishing distinct structural subgroups with either a high degree of disorder or with some partial $\beta$-sheet structure $[12,24,34]$. It is possible that a subset of oligomers formed during the transition of the protein from the unfolded monomeric to the $\beta$-sheet fibrillar forms contains some $\alpha$-helical structure, although it is surprising to believe that the population of such subset could reach such high protein mass percentages at any time of the reaction at the typical conditions used to induce $\alpha$ Syn fibril formation [35]. Further studies would be required to clarify these initial observations.

The typical low populations of oligomers accumulated during the reaction of fibril formation and their heterogeneous and transient nature, has generally prevented the detection of such species in both cellular (as we do not have also specific good probes for their detection) and in vitro experiments. As a consequence, there are not yet detailed structural studies at atomic resolution for an $\alpha$ Syn oligomeric form (again oligomer referring as a different structural entity with respect to fibrils) in comparison to a large number of structures of different polymorphs of fibrils already available [36]. Kinetically-trapped $\alpha$ Syn oligomeric species isolated either by the use of compounds able to inhibit their conversion to fibrils or by the use of alternative amyloid pathways with particularly high energetic barriers between oligomeric and fibrillar forms of the protein are particularly useful for obtaining insightful information about these otherwise transient species [30, 37].

Polyphenol(-)-epigallocatechingallate (EGCG), baicalein, nicotine, dopamine, $\mathrm{H}_{2} \mathrm{O}_{2}$ and 3,4-dihydroxyphenylacetic acid have been frequently used to promote $\alpha \mathrm{Syn}$ oligomerization in vitro [38-43]. These treatments generally result in the oxidative modification of $\alpha$ Syn which leads to the accumulation of oligomers, typically by modifying the structure of the oligomers and preventing them to continue their evolution to mature fibrils. These modified oligomers are usually disordered and non-toxic (see [30] for a more detailed review of different structural types of $\alpha$ Syn oligomers). A different structure, however, has been proposed for the oligomers formed in the presence of the reactive aldehyde 4-oxo-2-nonenal (ONE) or 4-hydroxy-2-nonenal (HNE), which were found to covalently modify $\alpha$ Syn in vitro and induce the formation of stable $\beta$-sheet-rich oligomers with neurotoxic properties [44, 45].

An alternative strategy used to generate stable $\alpha$ Syn oligomeric samples involves the induction of particular mechanisms of amyloid self-assembly. We have recently observed that $\alpha$ Syn can form amyloid aggregates with similar $\beta$-sheet content to that of the typical fibrils, with all the structural hallmarks of amyloid structures, but with smaller sizes and 
with a preference for an antiparallel $\beta$-sheet arrangement, in contrast to the parallel $\beta$-sheet architecture observed for the fibrils generated under the typical in vitro conditions used to trigger $\alpha$ Syn self-assembly. We established that this alternative amyloid $\beta$-sheet structure was preferred when the process of self-assembly was triggered by homogeneous nucleation and that this type of nucleation was favoured under limited hydration conditions. Indeed, we noticed that the formation of amyloid aggregates rich in intermolecular antiparallel $\beta$-sheets under limited hydration conditions was already reported for other amyloidogenic peptides, and a multitude of a priori non-amyloidogenic proteins belonging to different structural classes, as well as disordered peptides such as poly(L-lysine) [46-50]. Under highly hydrating conditions, primary nucleation in $\alpha$ Syn is slow, being facilitated by the presence of hydrophobic/hydrophilic interfaces such as the air/water interface (heterogeneous nucleation). The pre-nucleus of the amyloid structure formed at these nucleation-active surfaces would inevitably adopt a parallel intermolecular $\beta$-sheet arrangement given the restrictions in the disposition and orientation of the polypeptide chains anchored through their $\mathrm{N}$-terminal amphipathic region to the interface. Under conditions of poor water activity, similar to those found in the interior of protein droplets generated by liquid-liquid phase separation, however, the desolvation energy barrier is significantly reduced, and nucleation can occur very rapidly in the bulk of the solution (homogeneous nucleation), giving rise to structurally distinct amyloid polymorphs, as there is no restriction in the orientation of the protein molecules in the bulk [51].

The antiparallel intermolecular $\beta$-sheet structure has been also previously observed in stable, particularly toxic oligomers of $\alpha$ Syn and other amyloidogenic systems and has been proposed to be distinctive of these toxic species [52-55]. These oligomers have been suggested to be off-pathway but, in the light of our new findings, they are best described as amyloid prefibrillar oligomers generated by homogeneous nucleation under limited hydration conditions. We noticed that a significant number of reported protocols to generate stable $\beta$-sheet oligomers include a lyophilization step or the peptide/protein stock is lyophilized, which suggests that similar types of oligomers to those generated under limited hydration conditions (with antiparallel $\beta$-sheet core) are formed.

These stable oligomers have been reported to represent good models to investigate the structural and biological properties of prefibrillar amyloid oligomers as they are homologous to the transiently populated parallel $\beta$-sheet oligomers that are formed during fibril formation through heterogeneous nucleation at the typical conditions used for in vitro fibril formation (air/water interface under shaking conditions) [54, 56]. However, not all the properties are similar or homologous, as the kinetically trapped nature of these species implies that they are deficient in elongating [57], in contrast to the transient parallel $\beta$-sheet oligomers, which are consequently difficult to trap. Importantly, this type of oligomers seems biologically analogous to the oligomeric species formed in cells, being the cellular effects that they induced (except seeding and propagating) similar to those observed in a PD cellular model obtained from iPSC-derived neurons from a patient with a triplication in the SNCA gene (the gene that encodes for $\alpha$ Syn) $[58,59]$.

These kinetically trapped, partially formed $\beta$-sheet oligomers present half of the $\beta$-sheet content $(\sim 30 \%)$ to that typically observed in the matured fibrils $(\sim 60-65 \%$, either in the parallel or antiparallel $\beta$-sheet fibrillar structures) and in average contain ca. 30 mers (although distribution of 15-40 mers is generally observed) [54]. The structural homogeneity of the oligomeric samples obtained following wellestablished protocols $[52,54,60]$ and the remarkably slow elongation and disaggregation rates of this type of oligomers $[54,61]$ have allowed their structural characterization in more detail by a wide variety of techniques: fluorescence [62] and infrared spectroscopy [52], mass spectrometry [63], SAXS [34, 60], NMR [64] or cryo-EM [54]. A consensus among all the structural studies can be extracted. These oligomers show a cylindrical/ellipsoidal morphology, similar to that previously reported for toxic prefibrillar oligomers [34]), with a diameter of ca. $10 \mathrm{~nm}$, that coincide with the diameter found for $\alpha$ Syn mature fibrils. However, in contrast to the $\alpha$ Syn fibrils whose structure has been determined up to date, these oligomers show a hollow core, suggesting that the interactions between $\beta$-sheets are predominantly hydrophilic and mediated by water molecules. This structural arrangement results in a significant fraction of hydrophobic residues exposed to the solvent at the surface of the oligomer structure [54], which combined with a flexible, partially formed core structure, explains the particular ability of these species to interact with the interior of the lipid bilayers and disrupt cellular membranes [64]. In contrast, the fibrillar forms of the protein have a highly rigid $\beta$-sheet core [65] which impedes its insertion into the lipid membranes [11]. The exposure of hydrophobic residues and hydrogenbond unsatisfied amino acid groups on the surface of these oligomeric species likely results also in the aberrant and promiscuous interaction of these species with other cellular components, which could disrupt their correct biological functions.

\section{Mechanisms of toxicity}

Accumulating evidence indicates that $\alpha$ Syn oligomers are toxic. They have been reported to locate at the degenerating regions in PD in vivo models $[66,67]$ and different reports have shown direct experimental evidences for toxic properties of oligomers in cells [28], with impaired $\alpha$ Syn variants 
for fibril, but not oligomer formation, showing the greatest toxicity $[3,4]$. In addition, certain in vitro generated oligomers were found to be particularly neurotoxic in vivo in different model organisms [3].

Several observations suggest that $\alpha$ Syn oligomers, similarly to other prefibrillar oligomers from other amyloidogenic proteins, can disrupt cell membranes, being this effect a primary event in $\alpha$ Syn aggregation toxicity [59, 64, 68-70]. The most likely mechanism is the direct interaction of such species with the cell membrane and the insertion of part of their amyloid core into the lipid bilayer [64], with the concomitant membrane disruption and aberrant ion efflux/ influx in the cell $[11,68]$. Such ion dyshomeostasis can promote oxidative stress by increasing reactive oxygen species (ROS) production and decreasing endogenous glutathione [59], but also abnormal calcium influx [58], which has been related to mitochondrial dysfunction [71].

Interestingly, in some of these studies, identical effects were observed in both inducible pluripotent stem cells (iPSC)-derived neurons bearing SNCA triplication that generates aggregates that promote oxidative stress and mitochondria dysfunction, as well as in primary rat co-cultures of neurons and astrocytes exposed to in vitro generated kinetically trapped $\alpha$ Syn oligomers with $\beta$-sheet structure of the type characterised in $[54,58,59,72]$. More recently, a direct interaction between $\alpha$ Syn oligomers and ATP synthase has been reported, which seems to result in the impairment of complex I-dependent respiration, the opening of the permeability transition pore and mitochondrial swelling, eventually causing cell death [72]. In agreement with these findings, earlier studies already showed $\alpha$ Syn aggregates accumulation in mitochondria in neurons in culture and in vivo, impairing complex-I function [71, 73]. Overall, different studies on the toxic effect of $\alpha$ Syn oligomers suggest that there are multiple mechanisms by which these species can induce mitochondrial dysfunction both in neurons and astrocytes [74, 75].

$\alpha$ Syn oligomers are formed inside cells but can also be internalised if present in the extracellular media by processes mediated in part by endocytosis $[57,76]$ and in part by other mechanisms [11]. The interaction of some types of oligomers with the plasma membrane of cells causes their perturbation, as pointed before, initiating a cascade of toxic effects [11]. In the interior of neurons, these oligomers are accumulated which in turn causes endoplasmic reticulum (ER) stress $[77,78]$ and proteostasis system dysfunction, apparently impairing both the proteasome and the autophagy-lysosomal degradation pathways $[79,80]$. $\alpha$ Syn oligomers have been reported to directly interact with some units of the proteasomal system, blocking the entry of other substrates and increasing the accumulation of misfolded proteins. At the same time, cellular insults such as oxidative stress have been shown to increase $\alpha$ Syn oligomer formation [81], further exacerbating an aberrant pathological feedback, which could be particularly deleterious in the high energy-demanding dopaminergic neurons, which also present high basal levels of oxidative stress [82].

In addition, other toxic effects have been associated with $\alpha$ Syn oligomers, including activation of pro-inflammatory cytokines in astrocytes and microglia [83]. Extracellular aggregated $\alpha$ Syn has been reported to interact with toll-like receptors on glial cells and trigger inflammatory responses which eventually cause neuronal death [83, 84]. In addition, $\alpha$ Syn aggregated species have also been reported to impair axonal transport in neurons [85] and promote synaptic dysfunction $[86,87]$ through aberrant interactions with NMDA receptors [88, 89]. Indeed, some studies have shown an increased negative impact on neuronal signalling for some types of oligomers with respect to either monomeric or fibrillar forms of $\alpha$ Syn [2]. The different neurotoxic pathways and cellular dysfunctions evoked by $\alpha$ Syn oligomers are reported in Fig. 1.

The multiplicity of the type of molecules that $\alpha$ Syn oligomers have been reported to directly interact with or indirectly affect could be associated in part with the variability of types of oligomers used in the different studies and the terminology used in some of these studies, where the name oligomers is used indiscriminately to also include fibrillar aggregates. Most studies on oligomers have not characterised the species of oligomers in detail, so it is extremely difficult to extract firm conclusions about the general role of these species in pathology. In any case, the amount of different studies on the toxic effects of $\alpha$ Syn oligomers reflects the diversity of aberrant interactions of these species to multiple cellular components, with detrimental consequences for the cell. The ability of these species to interact aberrantly with such multiple types of molecules is likely a consequence of the particular structural attributes of these species, as explained before. Such attributes are likely to be common to other hydrophobic, partially $\beta$-sheet formed oligomers from other amyloidogenic proteins [22, 90, 91], although structural peculiarities among the different types of oligomers probably imply specific interactions and mechanisms of toxicity for distinct types of oligomers. It is very important, therefore, to classify structural groups of oligomers and identify their properties and effects to clarify their role in disease.

Synucleinopathies, as well as other amyloid-associated neurodegenerative diseases, have a distinct progression pattern for neurodegeneration in the brain concomitant with the appearance of $\alpha$ Syn pathology, suggesting a neuropathological propagating role of $\alpha$ Syn.

$\alpha$ Syn oligomers can induce neurotoxicity in a variety of ways and can be propagated from cell to cell, properties that have made the scientific community to consider them as key players in the aetiology of synucleionopathies. Given that 


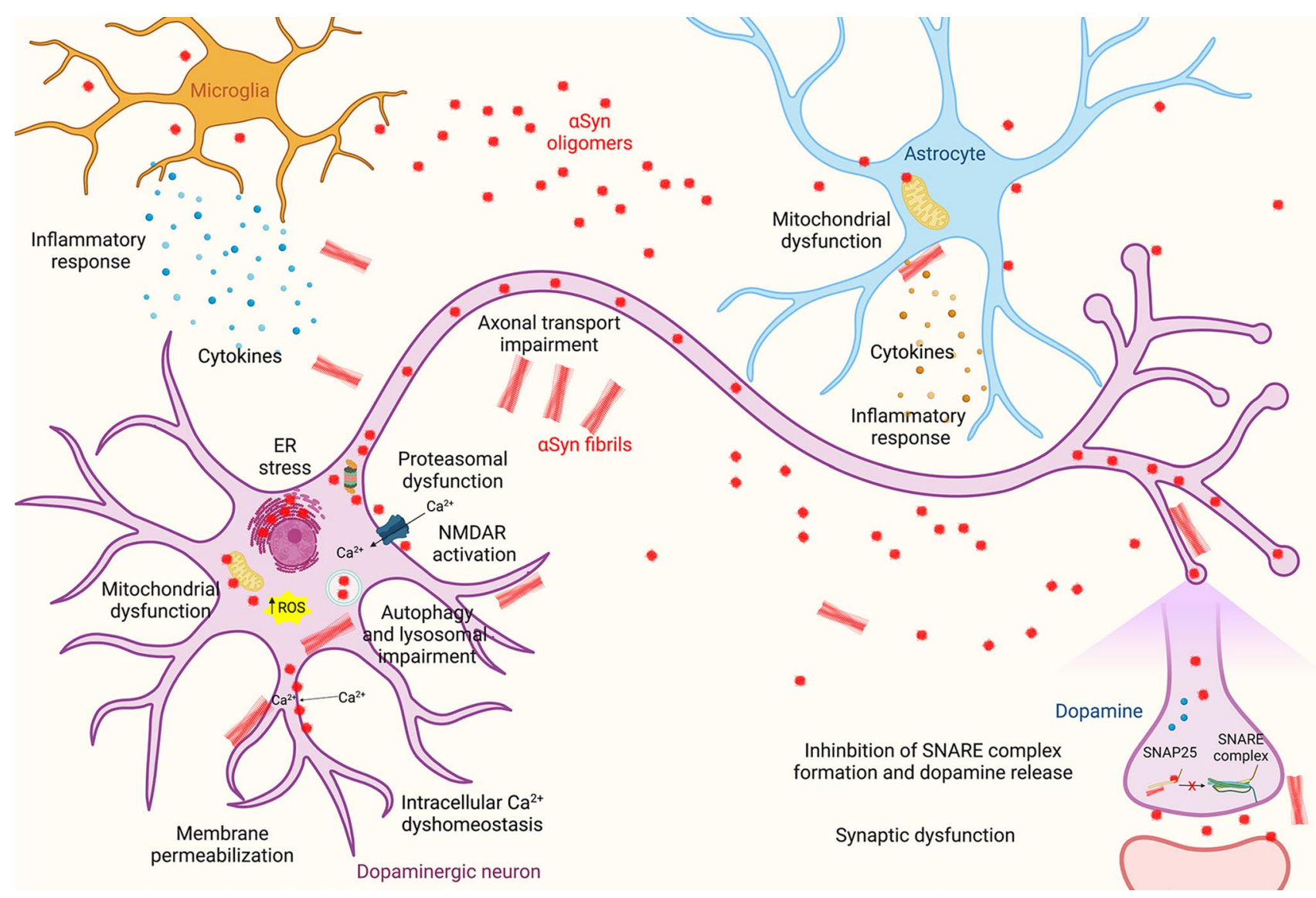

Fig. 1 Primary mechanisms of $\alpha$ Syn aggregate toxicity. A myriad of mechanisms has been proposed for the induction of toxicity by $\alpha$ Syn oligomers and fibrils. In this schematic representation have

a primary event of oligomer toxicity involves perturbation of neuronal membranes, a number of molecules and strategies have been designed to target the interaction of oligomers with these cellular structures, which, indeed, have been reported to elicit beneficial effects in different cellular and animal models [56, 92-97]. Some of these molecules are being tested as potential therapeutic agents.

Immunotherapy could be an alternative method to target $\alpha$ Syn pathology. In this respect, monoclonal antibodies developed to target oligomeric $\alpha$ Syn were used to treat transgenic mice expressing high levels of $\alpha$ Syn and the researchers found reduced levels of $\alpha$ Syn in the central nervous system (CNS) [98]. Following a similar idea, Spencer et al. [99] used lentivirus-mediated delivery of oligomerselective nanobodies (single chain antibodies) to increase the intracellular presence of antibodies inside the CNS and shown to reduce $\alpha$ Syn pathology and motor symptoms in transgenic mice. These findings together with similar results obtained from other groups have prompted clinical studies of $\alpha$ Syn immunotherapy in humans. Although the first results recently obtained from these clinical studies are less been highlighted some of the most well-documented mechanisms, as explained in the text. Created with BioRender.com

encouraging than expected, efforts in improving the delivery of antibodies inside neurons in the CNS, as well as in developing antibodies that truly target specifically the toxic aggregated forms of $\alpha$ Syn that form in vivo, without affecting the monomeric, functional form of the protein, should continue to really validate this approach as an effective therapy.

At the same time, increased levels of $\alpha$ Syn oligomers in brains and CSF have been measured in individuals with LB-related pathologies compared to control subjects [26, $100-105]$, suggesting that $\alpha$ Syn oligomers could be relevant biomarkers present in human biofluids which could guide earlier diagnosis and more effective prognosis, as well as for therapy evaluation studies in synucleionopathies. To detect these species in patient samples, efficient and highly specific detection methods are required. Some current approaches to detect aggregated $\alpha$ Syn in human biofluids use a PMCA (amplification cycle) approach. Interestingly, this technique has been recently shown to be able to discriminate patients with PD from patients with MSA [106]. The approach consists of multiplying primarily the $\alpha$ Syn aggregates with the highest elongation capabilities and, therefore, will enrich 
the sample in aggregates with the faster rates of elongation, which are likely to consist of particular types of fibril polymorphs. It is yet unclear whether these approaches are effective in detecting oligomeric species, being those different species with respect to fibrils. In any case, this approach shows a great potential for differential diagnosis and it represents a huge step towards the specific and earlier diagnosis to distinct types of synucleinopathies. Other methods to identify and quantify $\alpha$ Syn oligomers as biomarkers in CSF or blood are based on ELISA detection, using primarily the monoclonal $\alpha$ Syn antibody 211 (epitope in C-terminal region of $\alpha$ Syn) for capture and detection, so they cannot discriminate between oligomeric and fibrillar forms or either different structural types of oligomers. In addition, these approaches can potentially cross-react with monomers if they are associated with vesicles, or other protein complexes. In this context, molecules that can bind specifically the toxic species of $\alpha$ Syn, even under conditions of a large excess of monomeric protein [56], can be very useful for developing diagnostic tools.

\section{Fibril toxicity}

\section{aSyn fibrils}

The accumulation of amyloid-like $\alpha$ Syn fibrils as intracellular inclusions in neurons (LBs) is one of the hallmarks of PD [107-111]. However, whether $\alpha$ Syn fibrils and LBs are the cause or consequence of synucleinopathies remains the subject of scientific debate. Indeed, the molecular and cellular mechanisms triggering $\alpha$ Syn misfolding, fibrillization, and LBs formation appeared unclear and are only partially characterized.

Monomeric $\alpha$ Syn self-assembly finally leads to the formation of highly compact and ordered fibrils that show the common amyloid features, such as the ability to bind Thioflavin $\mathrm{T}$, the presence of a $\beta$-sheet structure and an elongated filamentous morphology $[45,52]$ and that have been found to be morphologically and tinctorially almost identical to those extracted from patients [112]. Several techniques have been employed for the structural characterization of $\alpha$ Syn fibrils, such as electron microscopy (EM), hydrogen exchange mass spectrometry, solid-state nuclear magnetic resonance (ssNMR), or electron paramagnetic resonance (EPR) [30]. Many accumulated evidences indicate that the core structure of $\alpha$ Syn fibrils generally includes residues $30-110$, is resistant to proteases and completely buried [113-116], whereas both the C-terminus (residues 100-140) and the $\mathrm{N}$-terminal region of the protein (residues 1-30) remain largely unstructured, although both regions seem to be involved in the interactions between protofilaments
$[114,117]$. Furthermore, $\alpha$ Syn fibrils adopt an antiparallel in-register $\beta$-sandwich fold.

All $\alpha$ Syn species are in equilibrium in solution and their concentration and life span depend on the environment of those molecules. Thus, $\alpha$ Syn conformers form and grow at different rates under different environmental conditions, leading to a variety of fibrillar polymorphs [118], which vary in the number and disposition of the protofilaments in the fibrils and in the strength of the amino acid interactions responsible for the $\beta$-sandwich fold $[114,116,119]$. EM studies have shown that, independently of the fibril polymorphism, several $\alpha$ Syn fibrils possess a low electron density region in the center of their structure [114], as they are formed by many protofibrils that, interacting with each other, form a tubular-like ultrastructure, in both twisted and straight fibrils [30]. Cryo-EM studies revealed that the residues 50-57 of $\alpha$ Syn fibrils are located at the interface of the interacting protofilaments. The various $\alpha$ Syn fibril polymorphs have been observed both in vitro and in vivo. In particular, negative-stain EM images of $\alpha$ Syn fibrils extracted from the brain of PD and MSA patients revealed the presence of 10-nm-wide straight or twisted filaments and a minor population of 5-nm-wide straight filaments [111]. Additional EM studies of recombinant $\alpha$ Syn fibrils confirmed the presence of similar fibrillar polymorphs [114].

To clarify the molecular mechanisms by which $\alpha$ Syn generates distinct fibrillar aggregates and triggers neurotoxicity, several structural analyses of $\alpha$ Syn fibril polymorphs have been carried out. The NAC domain of $\alpha$ Syn is the hydrophobic core of the protein formed of 12 amino acids that are responsible for its fibrillogenesis [120]. More than six different amyloid fibril structures of $\alpha$ Syn have been solved by cryoEM or ssNMR $[36,121]$, and all the fibril cores contain the NAC region [120]. Notably, between 50 and $70 \%$ of the 140 residues of $\alpha$ Syn are not involved in the cross- $\beta$ amyloid core. In particular, structures of the preNAC and NAC regions have been resolved by micro-electron diffraction (microED) [122], revealing the presence of a pair of tightly mated in-register $\beta$-sheets forming a steric zipper. Moreover, ssNMR analysis of recombinant $\alpha$ Syn revealed a Greek-key $\beta$-sheet motif in the hydrophobic core of a single fibril filament [119], where salt bridges (E46-K80), a glutamine ladder (Q79), and hydrophobic packing of aromatic residues (F94) contribute to the stability of the in-register $\beta$-sheet. The different $\alpha$ Syn fibril polymorphs were found to exhibit different toxicity and seeding properties both in vitro [123] and in vivo [124]. Recent studies demonstrated that brainderived $\alpha$ Syn fibrils from different synucleinopathies are distinct in seeding potencies [125]. However, additional studies are needed to elucidate the differences between $\alpha$ Syn fibril polymorphs, and to develop new therapeutic approaches targeting $\alpha$ Syn aggregation and seeding. 
Recent NMR and circular dichroism (CD) data have shown that the $\beta$-sheet core of the $\alpha$ Syn fibrils are unable to establish persistent interactions with either the surface or the internal regions of the lipid bilayers, with the interactions restricted to the binding of the disordered $\mathrm{N}$-terminal region of $\alpha$ Syn onto the surfaces of the lipid bilayers [11]. Accordingly, at early incubation time, $\alpha$ Syn fibrils appear to be largely localized at the surface of the plasma membrane. Furthermore, the total quantity of fibrils bound to the cell membrane was not found to correlate with the degree of cell dysfunction or $\alpha$ Syn penetration [11]. Therefore, the association between fibrils and cellular membranes is not sufficient to account for the toxicity of these species.

Stress conditions cause the imbalance of neuronal proteostasis leading to pathological situations [126, 127]. Even if the aggregation of $\alpha \mathrm{Syn}$ is independent of cellular proteostasis, the life span and concentration of the aberrant species depend on cellular proteostasis. Furthermore, it is well known that point mutations (A30P, E46K, H50Q, G51D, or A53T) and gene duplication/triplication within SNCA, the gene encoding $\alpha \mathrm{Syn}$, are associated with increased aggregation propensity and familial early-onset forms of PD [128-132]. Indeed, these gene alterations increase the number of possible $\alpha$ Syn conformations and life span, thus favouring its aggregation. In particular, A30P and A53T mutations promote fibril formation more rapidly than the wild-type $\alpha$ Syn protein and are more prone to $\alpha$ Syn toxicity. Although LBs are characterized by the presence of $\alpha$ Syn fibrils with $\beta$-sheet conformation [122], in vitro studies have shown that A30P and A53T $\alpha$ Syn mutations induce the formation of oligomers with respect to fibrils [133]. In addition, both wild type and mutants A30P and A53T $\alpha$ Syn can form insoluble $\beta$-sheet structured fibrillar aggregates at physiological temperature.

Recent EM and proteomic studies have shown that LBs are formed by a complex mixture of aggregated forms of $\alpha$ Syn and numerous other proteins, lipids, parts of membranes and organelles [134]. However, the role of these proteins in $\alpha$ Syn aggregation and the biogenesis of LBs remains poorly understood. Recent results demonstrated that the formation of $\alpha$ Syn fibrils occurs before the formation of LB-like inclusions [135], but what triggers $\alpha$ Syn fibrillization remains elusive. Previous studies have focused on the role of several proteins as modifiers of $\alpha$ Syn aggregation, inclusion formation, and toxicity. Recently, the aminoacyl tRNA synthase complex-interacting multifunctional protein 2 (AIMP2) has been pointed as an essential promoter of $\alpha$ Syn aggregation, inclusion formation and cytotoxicity [136]. Although AIMP2 has been suggested to be toxic to dopamine neurons, it showed a self-aggregating property acting as a seed to increase $\alpha$ Syn aggregation via specific and direct binding to the $\alpha$ Syn monomer. AIMP2 aggregates have been found to bind to monomeric $\alpha$ Syn, colocalizing with pS129 $\alpha$ Syn aggregates and inclusions in several models of synucleinopathies. These findings, however, lack of supporting data on the role of AIMP2 in aSyn aggregation or inclusion formation, suggesting that other mechanisms need to be discovered.

\section{Mechanisms of toxicity}

The $\alpha$ Syn encoding gene, SNCA, is a major genetic risk locus for idiopathic and familial PD [137-139]. $\alpha$ Syn is found both in the cytosol and in the extracellular interstitial fluid. The oligomeric species were observed in the cerebrospinal fluid (CSF) of PD patients [140], promoting the seeding and aggregation of monomeric $\alpha$ Syn $[141,142]$. The study of neuronal degeneration induced by intracellular $\alpha$ Syn is limited by the difficulties of generating in vitro intracellular aggregated species. On the other hand, the toxicity of extracellular species can be more easily monitored. Indeed, $\alpha$ Syn pathology can be triggered in experimental animals after intracerebral, intramuscular, or intravenous inoculation of brain homogenates from affected mice and patients, or recombinant fibrillar $\alpha$ Syn $[15,125,143-146]$. After neuronal transplantation in the brain of PD patients, grafted neurons showed LB-like inclusions [147, 148]. Furthermore, the injection of aggregated $\alpha$ Syn was found to cause the loss of nigral dopaminergic neurons $[15,144$, 149].

The most widely accepted paradigm postulates that prefibrillar oligomers, with respect to mature fibrils, represent the neurotoxic agents in PD [4, 133]. Nevertheless, some researchers found that $\alpha$ Syn fibrils are toxic themselves, because of their ability to bind and permeabilize the plasma membrane, thus inducing several alterations in cultured cells, such as $\mathrm{Ca}^{2+}$ dyshomeostasis [150] and mitochondrial dysfunction [151]. However, a direct quantitative in vivo comparison of the neurotoxic potential of different $\alpha$ Syn conformers is lacking. Fibrillar forms of $\alpha$ Syn have been reported to be both toxic and non-toxic [12, 40, 45, 68]. However, $\alpha$ Syn fibrils can contribute to neurodegeneration by different pathways: alteration of ionic homeostasis, seeds of soluble $\alpha$ Syn into higher molecular weight aggregates [23], perturbation of cellular proteostasis [126, 127], alteration of the integrity or function of cytosolic organelles [152], and activation of chronic inflammation [153-155]. Furthermore, there is evidence that the formation of fibrils, rather than toxic species themselves, mediates $\alpha$ Syn toxicity [109]. In particular, the fibrillary species, as opposed to the oligomeric forms, have been shown to propagate the pathology by recruiting endogenous $\alpha$ Syn when injected into animal models [16]. Indeed, $\alpha$ Syn fibrillar species generated in vitro cause neuronal degeneration and trigger the aggregation of endogenous $\alpha$ Syn several months after injection into the 
central nervous system (CNS), similar to brain homogenates from PD or MSA cases [14, 16, 17, 124].

Preformed $\alpha$ Syn fibrils were also found to cause the loss of the proteins VAMP2 and SNAP-25 that are associated with the soluble NSF-attachment protein receptor (SNARE) complex in primary neuronal cultures. These fibrils also reduced the levels of two proteins involved in the synaptic vesicles (CSPa and synapsin-2) [17]. The researchers further investigated the impact of the accumulation of these preformed $\alpha$ Syn fibrils in neuronal degeneration. In particular, they found that impaired hippocampal network activity occurred much earlier than the loss of synaptic proteins, suggesting that $\alpha$ Syn pathology can have a major impact on the coordination of neuronal communication and connectivity [17]. $\alpha$ Syn preformed fibrils also induced robust inflammatory transcriptional signalling in human midbrain astrocytes [156]. The major neurotoxic effects of $\alpha$ Syn fibrils are represented in Fig. 1.

The deleterious effects of $\alpha$ Syn may exist independently of endogenous $\alpha$ Syn. Indeed, neurotoxicity can be differentially affected by the type of $\alpha$ Syn aggregates added to cells and oligomer-induced cell death did not promote the aggregation of endogenous $\alpha$ Syn $[11,68]$.

We have recently demonstrated that the toxic effects of the fibrils are directly correlated with the amount of $\alpha$ Syn that penetrate into the neuronal cells after interacting with the cellular membranes and cause calcium uptake, ROS formation, membrane permeabilization, caspase-3 activation and mitochondrial dysfunction [11]. In particular, we provide further evidence for the release of toxic oligomeric species from fibrils, upon extracellular administration of $\alpha$ Syn fibrillar species to neuronal cultures, using specific probes able to distinguish them from their fibrillar precursors [11, 157], (Fig. 2).

According to our results, the dissociation of $\alpha$ Syn fibrils into soluble $\alpha$ Syn species, likely to include a low proportion of monomers in addition to oligomers, have also been observed in recent studies to occur under conditions close to physiological $[12,158]$. These conclusions are in line with previous reports obtained with the amyloid beta $(\mathrm{A} \beta)$ peptide associated with Alzheimer's disease that have revealed the lipid-mediated depolymerization of non-toxic fibrils
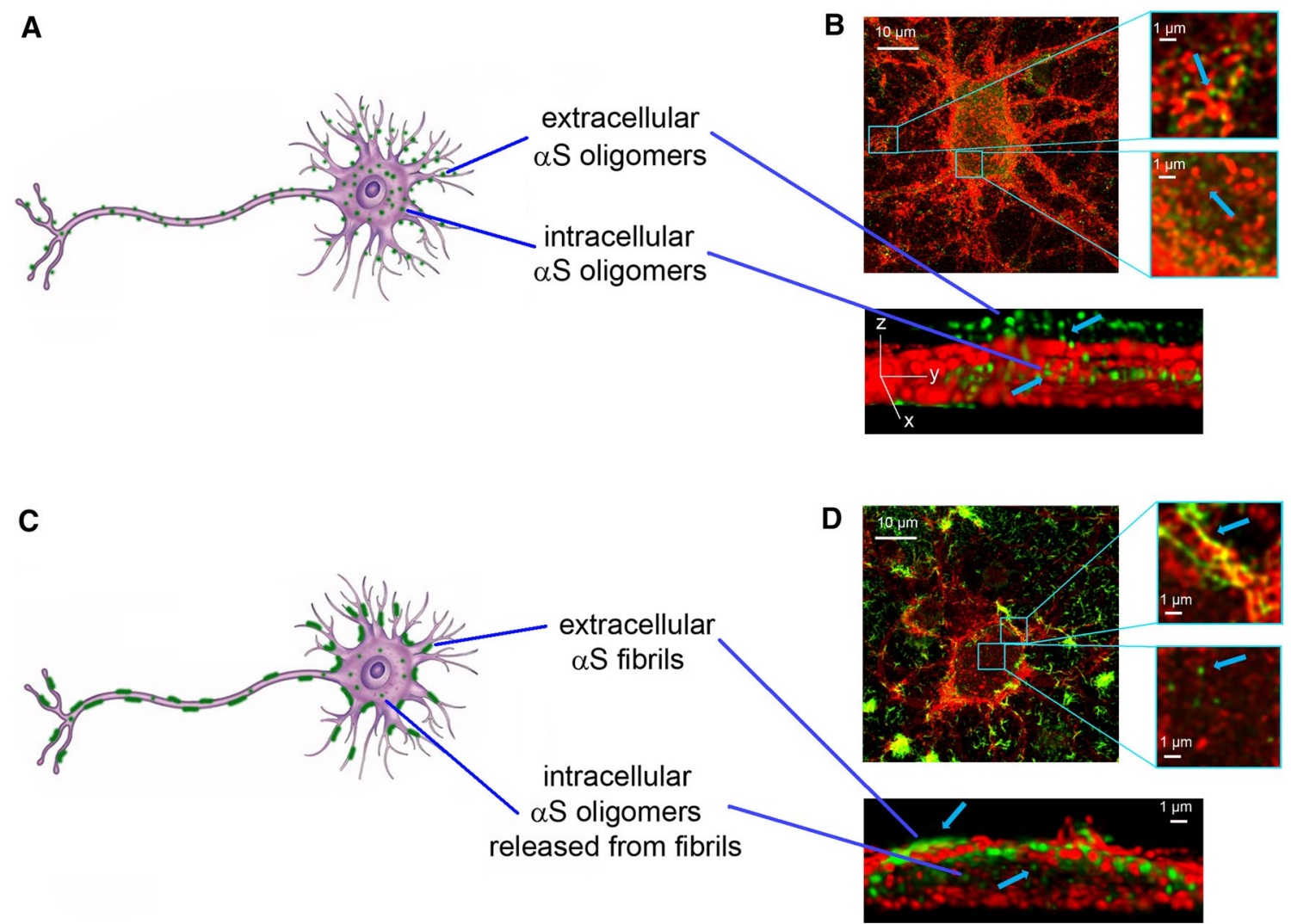

Fig. 2 The release of $\alpha$ Syn oligomers from mature fibrils. Schematic representation of neurons exposed to $\alpha$ Syn oligomers (A) and fibrils (C). Representative STED images of primary rat cortical neurons treated with preformed oligomers (B) and fibrils (D) with higher magnifications in the boxed areas on the right. Red and green fluorescence indicates the cell membranes and the $\alpha$ Syn species, respec- tively. A 3D reconstruction of a primary neuron on the $z y$ plane shows the extracellular (top) and intracellular (middle) $\alpha \mathrm{S}$ species. STED images reprinted from [11], licensed under Creative Commons Attribution 4.0 International Public License (CC BY 4.0,https://creat ivecommons.org/licenses/by/4.0/) 
of $\mathrm{A} \beta$ into toxic $\mathrm{A} 11$-positive oligomers, which were also shown to resemble the oligomers formed de novo during fibril assembly [159]. They are also in agreement with the general proposition that any fibrillar species that accumulate in tissue can represent a source of soluble toxic oligomers $[12,160]$, and with the halos of soluble oligomers observed to surround amyloid plaques of $A \beta$ in mouse brains [161].

This evidence suggests that $\alpha$ Syn fibrils, in addition to their ability to transfer from neuron-to-neuron contributing to the progressive diffusion and spreading of LB pathology in different brain areas [15, 17, 57, 124, 143, 162-164], can release prefibrillar oligomeric species that cause an immediate dysfunction of the neurons in the vicinity of these species $[11,157]$ (Fig. 2). Such released oligomeric species could also contribute to pathogenesis via neuron-to-neuron spreading by their direct cell-to-cell transfer or by generating new fibrils, following their neuronal uptake.

\section{Fibril spreading}

\section{aSyn, a prion-like protein}

Prions were firstly defined by Stanley Prusiner as "proteinaceous infectious particles" able to transmit cell-to-cell, thus causing the propagation of specific diseases [165]. This term arises from the misfolding of endogenous native cellular prion protein $\left(\mathrm{PrP}^{\mathrm{C}}\right)$ into a pathogenic conformation referred to as scrapie $\left(\mathrm{PrP}^{\mathrm{Sc}}\right)$, able to recruit and corrupt $\operatorname{PrP}^{\mathrm{C}}$, thus inducing the formation of misfolded conformers with self-propagating capacities [166]. Similarly, several proteins involved in the most widespread neurodegenerative diseases, such as $\alpha$ Syn [15], tau [167], amyloid- $\beta$ [168] and Huntingtin [169], were extensively reported to adopt a similar spreading mechanism.

Staging studies of PD support the prion-like nature of $\alpha$ Syn, as its aggregated forms appear in the brain following a well-defined spatially and temporally stereotyped fashion [170-173]. The so-called Braak hypothesis posits that $\alpha$ Syn from LBs and LNs spreads between synaptically connected brain areas [172-174]. This transmission would be responsible for the propagation of the pathology and strongly correlates with the progression and the severity of the disease-associated symptoms. According to this theory, Lewy pathology is initiated by an undefined pathogen (virus or bacterium) that enters in the nasal cavity, and subsequently reaches the gut [173], the pathogen spreads via the olfactory tract or the vagus nerve, joining the central nervous system (CNS, and in particular the medulla oblongata and the olfactory bulb), thus causing deficits in the sense of smell, that are early markers of the preclinical phases of PD (Braak stages 1 and 2); the propagation carries on into the brainstem, thus inducing sleep and motor disturbances (Braak stages 3 and 4), then into the limbic system, finally reaching the neocortical regions, determining cognitive impairment and emotional disturbances in Braak stages 5 and 6 [175]. Braak staging of PD is supported in vitro, in vivo, and by the vast majority of clinical cases, in particular those with early onset and longest disease duration [176]. Many studies conducted both in humans and model systems clearly indicate that $\alpha$ Syn aggregates can be released from neurons [177], and subsequently taken up by the nearby, thus inducing Lewy pathology. Furthermore, $\alpha$ Syn is largely present, in different aggregated forms, in biological fluids such as CSF, plasma, and saliva $[105,177,178]$. In addition, clinical evidence from post-mortem analysis of PD patients who received donor nigral grafts showed that more than 10 years after, Lewy pathology was also present in healthy donor neurons, indicating $\alpha$ Syn spreading from unhealthy neurons of the host brains [147, 148].

When $\alpha$ Syn preformed fibrils (PFFs) were injected into the brain of transgenic mice overexpressing human A53T $\alpha$ Syn, $\alpha$ Syn aggregation and LBs formation were massively exacerbated by the uptake of PFFs; these aggregates were also injected in mice brains overexpressing the wild-type protein, and LB-like inclusions were found to spread through the mouse brain following a precise spatiotemporal pattern [15]. Many other investigations have been performed in animal models such as mice [16, 143, 179] and rats [144]. It has been shown that small fibrillar aggregates are particularly effective in seeding and spreading when injected into non-transgenic mouse brains, while long fibrils are largely inefficient [57], suggesting that oligomers with high seeding capabilities might also be implicated in $\alpha$ Syn pathology propagation. Some studies have reported that different types of $\alpha$ Syn oligomers are capable to seed $\alpha$ Syn aggregation in cells and propagate $\alpha$ Syn pathology $[68,180]$. However, other studies trying to analyse the role of oligomeric species in this process have used in vitro generated/stabilised $\alpha$ Syn oligomers, which typically show impaired elongation/ seeding properties as a consequence of the protocols used to trap them [21, 54, 57]. In all cases, the injection of $\alpha$ Syn aggregates induces the formation of LB-like inclusions, thus leading to the spreading of $\alpha$ Syn pathology and, as a consequence, to the death of vulnerable neuronal populations, thus recapitulating the main features of PD. Collectively, these evidences suggest that $\alpha$ Syn aggregates are able to self-propagate and spread in a prion-like manner, acting as seeds, and inducing the misfolding of soluble native $\alpha$ Syn, thus initiating pathology in recipient neurons. Importantly, the synaptic connection between different brain regions is necessary but not sufficient for causing neuronal cell death, that is strongly associated with the intrinsic vulnerability of specific neuronal populations [181]. Evidences obtained in the aforementioned animal models also indicated that the distribution of pathological lesions in the brains of injected 
rodents are strictly associated with the biophysical, structural and biochemical characteristics of the assemblies, thus corroborating the hypothesis of the existence of distinct $\alpha$ Syn conformers in vivo. This is consistent with the proposition of the prion-like behaviour of $\alpha$ Syn, as prions exist in distinct stable conformations, commonly referred to as strains, possessing distinct but relevant pathological, clinical, and diagnostic implications. [106, 121, 123, 124, 182]. Recently, filament preparations from MSA brains were used for the in vitro seeded assembly of recombinant human $\alpha$-synuclein [183]. The researchers found that the structures of the seeded assemblies differ from those of the seeds, suggesting that additional, as yet unknown, factors play a role in the propagation of the seeds [183]. Thus, identification of these factors will be essential for understanding the prionlike spreading of $\alpha$-synuclein proteinopathies.

\section{The release of aSyn fibrils}

In the last decades, major efforts have been performed to clarify the spreading mechanism of $\alpha$ Syn fibrils between interconnected vulnerable brain regions and Lewy pathology propagation, and a range of different cellular and animal models have been used to explain its transmission.

The ability of neurons to excrete $\alpha$ Syn monomers, oligomers, and fibrils through non-conventional calciumdependent exocytosis from vesicles or exosomes has been widely described [79, 184]. In particular, Lee et al. [185] reported a misfolding-associated protein secretion pathway which uses the endoplasmic reticulum (ER)-associated deubiquitylase USP19 to export aberrantly aggregated proteins, including $\alpha$ Syn. Concomitantly, Fontaine and coworkers showed that the co-chaperone DnaJC5, in complex with the chaperone Hsc70, are critically involved in the release of neurodegenerative disease proteins $\alpha$ Syn, tau and TDP-43 [186]. However, it is not clear if these two pathways are connected and if they are involved in the release of oligomeric or fibrillar forms of $\alpha$ Syn. Importantly, Hsc70 was previously reported to bind $\alpha$ Syn fibrils with much major affinity as compared to the soluble protein in vivo, and that the neurotoxicity of fibrillar conformers coated with Hsc70 was significantly minor with respect to that of uncoated ones, suggesting a possible role of this chaperone in reducing the spreading of $\alpha$ Syn fibrils throughout the CNS [151].

The release of $\alpha$ Syn fibrils from neurons has been investigated by taking advantage of microfluidic cell culture chambers, sophisticated tools allowing the separation of neuronal processes from somata via a series of interconnected microgrooves, in fluidically isolated channels [187]. Volpicelli-Daley and coworkers showed that $\alpha$ Syn PFFs were internalized when added to the neuritic chamber, or either to somata, of primary hippocampal neurons, resulting in insoluble phospho- $\alpha$ Syn-positive aggregates in different cellular compartments, resembling those found in the brain of people affected by synucleinopathies [17]. Fluorescently labelled $\alpha$ Syn PFFs were also reported to be internalized by primary neurons, transported in axons and rapidly observed in the cell bodies of immature second-order neurons following anterograde axonal transport [188], the secretion of $\alpha$ Syn fibrils occurs in the absence of axonal lysis, suggesting that their propagation from neuron to neuron occurs in healthy cells [162]. This observation is consistent with that obtained in vivo in a rat model overexpressing $\alpha$ Syn in the medulla oblongata, in which $\alpha$ Syn release from degenerated neurons did not result to cause a significant spreading to more rostral brain areas; by contrast, $\alpha$ Syn propagation was significantly more pronounced in intact healthy neuronal cells [189]. Using a three-chamber microfluidic device, Mao and coworkers reported that PFF added to the first chamber can transmit and induce the aggregation of endogenous $\alpha$ Syn in synaptically connected neurons in the other two chambers [190]. Consistently, the addition of specific $\alpha$ Syn monoclonal antibodies to the culture medium blocked the entry of PFFs in primary neurons, and the subsequent spreading of $\alpha$ Syn pathology to the nearby cells. Accordingly, the administration of such antibodies to a wild-type mouse previously inoculated with PFFs was able to reduce $\alpha$ Syn spreading, neuronal loss, and the associated motor dysfunction triggered by $\alpha$ Syn pathology [191].

Tunneling nanotubes (TNTs), F-actin-containing membranous channels connecting two or more remote cells [192], have been reported to play a major role in the transmission of $\alpha$ Syn fibrils between neurons. Abounit and coworkers revealed for the first time that $\alpha$ Syn fibrils directed to lysosomes for being degraded, were able to transfer between neuronal cells inside lysosomal vesicles via TNTs, and to induce the aggregation of endogenous $\alpha$ Syn [193]. Accordingly, lysosomal impairment was described to increase $\alpha$ Syn transfer between cells [194]. Recently, the mechanism by which $\alpha$ Syn fibrils spread through lysosomes was described in more detail: they were reported to alter lysosomal morphology and functionality, and to induce the peripheral redistribution of lysosomes, thus increasing their transfer to neighboring cells [195]. The transmission of $\alpha$ Syn fibrils through TNTs was also observed by Dieriks and collaborators in SH-SY5Y cells and in primary human brain pericytes derived from postmortem PD brains, pointing out the central role of non-neuronal cells in PD progression [196].

Importantly, other amyloidogenic proteins, including the prion protein [193, 197, 198], tau [197, 199, 200], and huntingtin [201] were previously described to transfer between cells through TNTs, suggesting that these cellular interconnections are primarily involved in the pathogenic spreading of misfolded protein aggregates between cells, and that they could be considered as suitable targets for therapeutic intervention in $\alpha$-synucleinopathies and other pathologies 
in which protein aggregation and prion-like spreading of misfolded aggregates is linked to neurodegeneration.

\section{The uptake of aSyn fibrils}

The uptake of $\alpha$ Syn fibrils from the extracellular space has been extensively investigated in recent years, as it is considered a crucial event resulting in neurotoxicity and seeding of the endogenous protein. Many research groups are focused on the uptake of $\alpha$ Syn fibrillar conformers by neurons, and constantly report significantly different kinetics, extent and mechanisms of uptake, given the use of diverse cellular models, culture conditions and aggregation protocols for fibril production, giving rise to distinct fibrillary strains with heterogeneous structural, biophysical and biological properties. Despite these differences, there is strong evidence of fibril internalization both in cultured cells [14, 17, $162,193,202,203$ ] and in vivo, in mouse models following the stereotactical injection of $\alpha$ Syn fibrils into the olfactory bulb: fibrils are uptaken by neurons and glia neighbouring the injection site [16].

$\alpha$ Syn fibrils bind to the extracellular leaflet of plasma membranes, and then gain entry into the cytosol of neuronal cells through different mechanisms, such as endocytosis, macropinocytosis, or by interacting with specific membrane receptors [204]. Among them, endocytosis has been widely investigated. Is has been demonstrated that the inhibition of dynamin-dependent endocytosis, either by low temperature, or through the expression of a dominant-negative mutant of dynamin-1, markedly decreases fibril internalization in different cell lines, including primary neurons [76, 163, 184, 193]. Very similar results were obtained when neuronal cells were treated with the dynamin inhibitor Dynasore [205]. The lymphocyte activation gene-3 (Lag-3), a member of the immunoglobulin superfamily of receptors, was reported to bind $\alpha$ Syn PFFs and to mediate their clathrin-mediated endocytosis. Accordingly, Lag-3 knockout reduced $\alpha$ Syn spreading in primary neurons and in mice CNS, thus preventing the subsequent aggregation of endogenous $\alpha$ Syn [190]. Importantly, the reduction was non total, and in the same study Mao and coworkers revealed that the Ab precursor-like protein 1 (APLP1) also act as a receptor leading to the entry of $\alpha$ Syn fibrils [190]. In very recent work, Zhang and coworkers investigated in more detail the molecular mechanism underlying the selective binding of fibrillar $\alpha$ Syn to neuronal cells through Lag-3 and APLP1 receptors, revealing that the acidic C-terminus of $\alpha$ Syn, particularly exposed on the surface of fibrillar conformers, is the key domain binding to a positively charged surface on the analysed receptors [206]. Importantly, S129 phosphorylation of $\alpha$ Syn, a typical modification of pathological $\alpha$ Syn abundant in Lewy bodies and neurites, determines a significant increase in the binding of $\alpha$ Syn fibrils to the receptors, thus promoting their spreading, finally culminating in neurodegeneration [206].

Over the last decade, heparan sulfate proteoglycans (HSPGs) emerged as a receptor and specific mediator for the uptake of $\alpha$ Syn, tau and A $\beta$ fibrils by macropinocytosis [207-209]. Such pathway occurs in neurons and oligodendrocytes, but not in immune cells of the brain like astrocytes and microglial cells, that probably employ different internalization mechanisms [210]. Accordingly, heparin was able to inhibit the binding on the cell surface and the internalization of $\alpha$ Syn fibrils [207], but this anticoagulant is not suitable for the chronic treatment of PD. Other researchers used a proteomic approach for the identification of other possible membrane interactors of $\alpha$ Syn fibrils, and they found that the $\alpha 3$-subunit of $\mathrm{Na}^{+} / \mathrm{K}^{+}$-ATPase ( $\alpha 3$-NKA) interacted with fibrillar, but not monomeric or oligomeric forms of $\alpha$ Syn [211]. Accordingly, mutations in the gene encoding $\alpha 3-\mathrm{NKA}$ (ATP1A3), has been associated with rapid-onset dystoniaparkinsonism [212]. The prion-like cell-to-cell transmission of fibrillar $\alpha$ Syn has been recently reported to be also mediated by the Fc gamma receptor IIb (Fc $\gamma$ RIIB), an inhibitory receptor physiologically present in the surface of neuronal cells, where it binds immunoglobulins $\mathrm{G}$ with low affinity $[213,214]$. The same receptor was also described for its ability to induce the accumulation of amyloid- $\beta$ oligomers [215], thus representing a common ligand for the neuropathic uptake of misfolded conformers in neurodegenerative diseases.

Mounting evidence suggests that $\operatorname{PrP}^{\mathrm{C}}$ is partially responsible for the uptake of $\alpha$ Syn fibrils [216]. Indeed, Aulić and collaborators reported that $\operatorname{PrP}^{\mathrm{C}}$ promotes the internalization of $\alpha$ Syn fibrils both in cultured cells and in vivo, in wild type $\left(\mathrm{Prnp}^{+} /^{+}\right)$mice as compared to PrP knock-out $\left(\mathrm{Prnp}^{-I^{-}}\right)$animals through the direct binding by its $\mathrm{N}$-terminal domain [216]. $\operatorname{PrP}^{\mathrm{C}}$ was also reported to facilitate the entry of tau [217] and TDP-43 [218] fibrils in neuronal cells, as well as to interact with $\alpha$ Syn [89] and amyloid- $\beta$ oligomers [219] and mediate their toxic downstream effects. Thus, $\operatorname{PrP}^{\mathrm{C}}$ is widely considered as a common cellular conformation-specific sensor for disease-associated proteins involved in neurodegeneration. Taken together, these evidences suggest that the reduction of cell-to-cell transmission of fibrillar $\alpha$ Syn could be a considerable therapeutic target to limit the disease to certain brain regions where inclusions are already present, thus avoiding their spreading. However, the plethora of possible mechanisms leading to the pathological transmission of harmful $\alpha$ Syn conformers, makes this challenge very complex.

Once internalized, $\alpha$ Syn fibrils are surrounded by endocytic membranes and directed to late endosomal compartments and lysosomes, without having a direct access to the wild-type, cytosolic, soluble $\alpha$ Syn $[76,193,202]$. 
Consistently, Sacino and coworkers [205] observed that when $\alpha$ Syn PPFs were added to the culture medium of neuronal-glial cells, they were progressively degraded, and that the inhibition of the lysosomal activity caused the accumulation of PPFs in vesicles. Interestingly, Loria and coworkers also reported lysosomal degradation of $\alpha$ Syn fibrils in astrocytes and, less efficiently, in neurons, suggesting a prominent role of astrocytes in clearing $\alpha$ Syn pathological deposits [220].

The precise escapement mechanism from the lumen of endocytic vesicles and the subsequent colocalization of $\alpha$ Syn fibrils with the endogenous $\alpha$ Syn are still a matter of debate, but this process was proposed to occur thanks to their ability to disrupt the integrity of endocytic membranes [221]. This evidence suggests that exogenous $\alpha$ Syn assemblies could act as nucleating seeds, able to recruit intracellular $\alpha$ Syn, giving rise to the formation of large insoluble LB-like inclusions [14, 17], imprinting their structural characteristics onto endogenous protein, and so causing its misfolding [123, 124]. An overview of the major molecular mechanisms responsible for the transmission of $\alpha$ Syn fibrils is given in Fig. 3. The so formed LB-like aggregates cause the global decrease of synaptic proteins, progressive impairments in neuronal excitability and connectivity, finally culminating in cell death [17]. These structures were found to be insoluble in detergent, hyperphosphorylated, ubiquitinated, and characterized by a filamentous ultrastructure revealed by electron microscopy [222].
Fig. $3 \alpha$ Syn fibrils spreading. $\alpha$ Syn fibrils are internalized by neuronal cells through endocytosis. Then, they reach the lysosomal compartment by travelling through early and late endosomes. $\alpha$ Syn fibrils escape the endosomal compartment through an undefined mechanism, and are released via exocytosis or tunneling nanotubes (TNT), thus reaching neighboring neurons and spreading the pathology. Created with BioRender.com

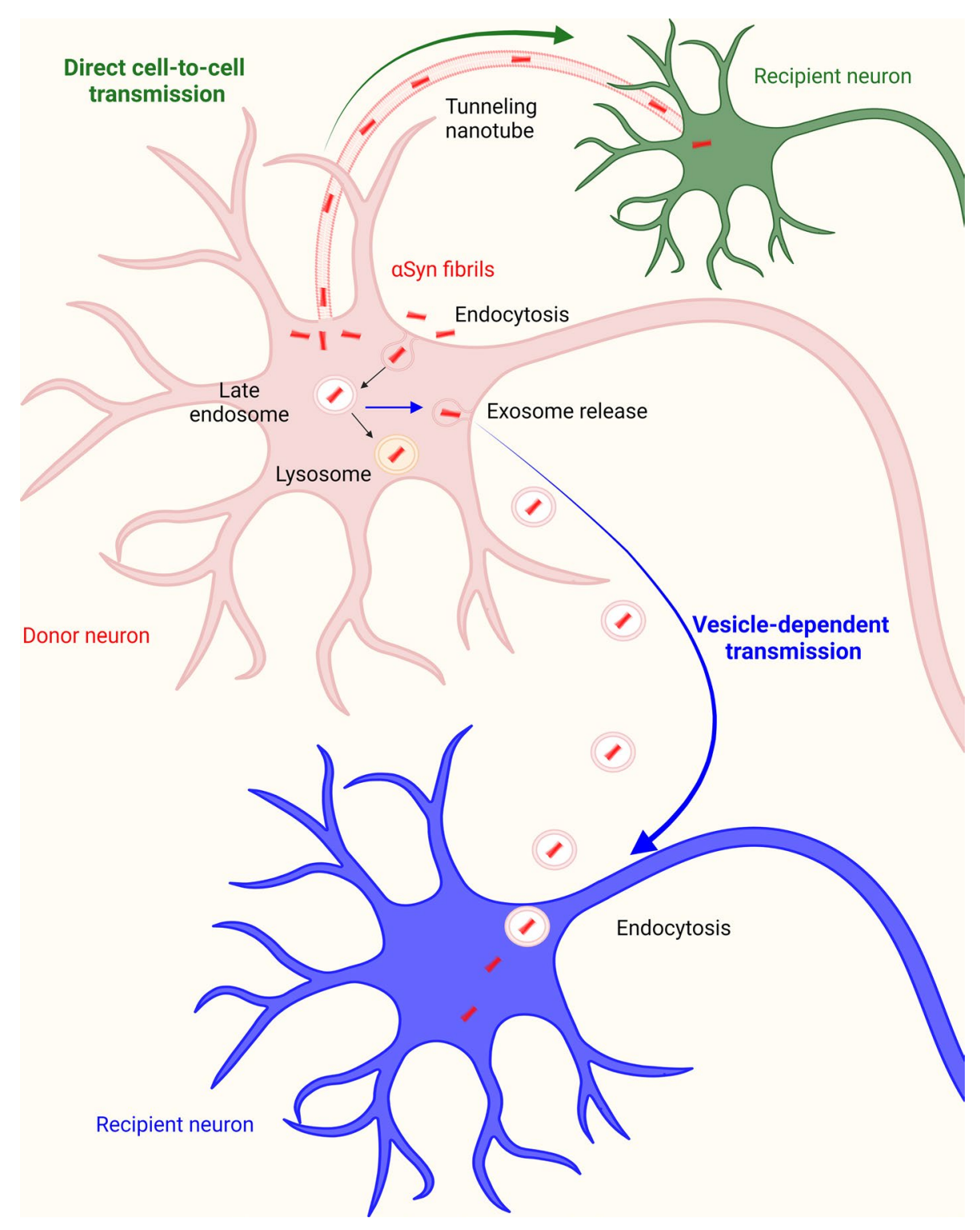


Fig. 4 Scheme of the main structural and biological features of aSyn species. Created with BioRender.com

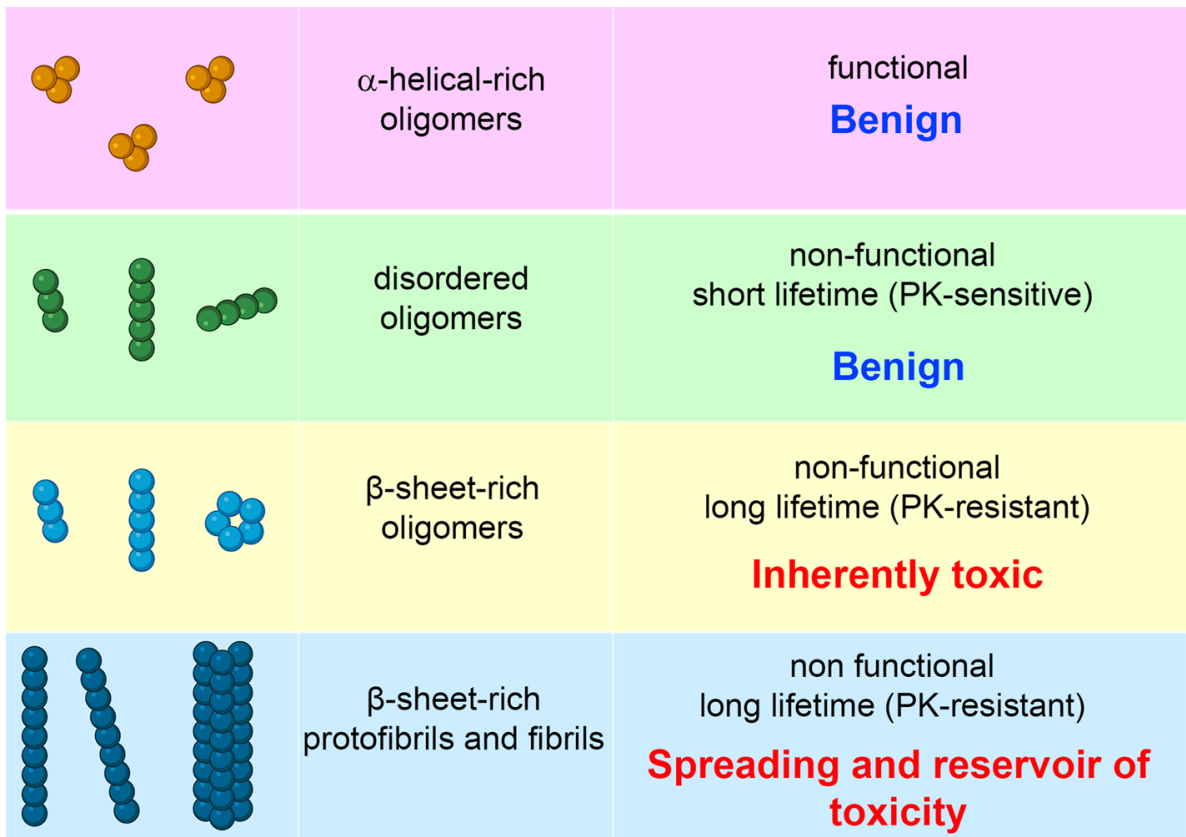

\section{Concluding remarks}

Protein misfolding and aggregation process in the cell can generate an ensemble of oligomers with differing $\beta$-sheet arrangements, rates of elongation and pathological roles (Fig. 4), depending on the nature of the biological processes occurring during the self-assembly pathway. In addition, the elongation prone, fibril-like oligomers with parallel $\beta$-sheet arrangement could act as pathogenic species for the spreading and transmission of the disease, whereas long-lived and protease-resistant oligomers with an antiparallel $\beta$-sheet arrangement could accumulate within cells and act as potent toxins. Recent NMR and $\mathrm{CD}$ data show that the $\beta$-sheet core of the $\alpha \mathrm{S}$ fibrils is unable to establish persistent interactions with the lipid bilayers, but they can release oligomeric species responsible for an immediate dysfunction of the recipient neurons. Reversibly, such oligomeric species could also contribute to pathogenesis via neuron-to-neuron spreading by their direct cell-to-cell transfer or by generating new fibrils, following their neuronal uptake. In conclusion, different types of aggregates populated during the process of $\alpha \mathrm{S}$ self-assembly appear to be involved with different molecular mechanisms in synucleinopathies: soluble oligomers are directly implicated in the induction of neurotoxicity and fibrils in the propagation of pathology.

Funding Open access funding provided by Università degli Studi di Firenze within the CRUI-CARE Agreement. The work was supported by the University of Florence (Fondi Ateneo to R.C and C.C.), the Ministry of Education, Universities and Research of Italy (Progetto Dipartimento di Eccellenza to C.C.) and the Spanish Ministry of Economy, Innovation and Universities (MICIU) with co-funding from EU (FEDER) (PGC2018-096335-B-100 to N.C.).
Data availability Enquiries about data availability should be directed to the authors. Data sharing not applicable to this article as no datasets were generated or analysed during the current study

\section{Declarations}

Conflict of interests The authors declare no competing interests.

Open Access This article is licensed under a Creative Commons Attribution 4.0 International License, which permits use, sharing, adaptation, distribution and reproduction in any medium or format, as long as you give appropriate credit to the original author(s) and the source, provide a link to the Creative Commons licence, and indicate if changes were made. The images or other third party material in this article are included in the article's Creative Commons licence, unless indicated otherwise in a credit line to the material. If material is not included in the article's Creative Commons licence and your intended use is not permitted by statutory regulation or exceeds the permitted use, you will need to obtain permission directly from the copyright holder. To view a copy of this licence, visit http://creativecommons.org/licenses/by/4.0/.

\section{References}

1. Cecchi C, Stefani M (2013) The amyloid-cell membrane system. The interplay between the biophysical features of oligomers/fibrils and cell membrane defines amyloid toxicity. Biophys Chem 182:30-43

2. Diógenes MJ, Dias RB, Rombo DM, Miranda HV, Maiolino F et al (2012) Extracellular alpha-synuclein oligomers modulate synaptic transmission and impair LTP via NMDA-receptor activation. J Neurosci 32:11750-11762

3. Karpinar DP, Balija MB, Kügler S, Opazo F, Rezaei-Ghaleh N et al (2009) Pre-fibrillar alpha-synuclein variants with impaired beta-structure increase neurotoxicity in Parkinson's disease models. EMBO J 28:3256-3268 
4. Winner B, Jappelli R, Maji SK, Desplats PA, Boyer L et al (2011) In vivo demonstration that alpha-synuclein oligomers are toxic. Proc Natl Acad Sci USA 108:4194-4199

5. Arrasate M, Mitra S, Schweitzer ES, Segal MR, Finkbeiner S (2004) Inclusion body formation reduces levels of mutant huntingtin and the risk of neuronal death. Nature 431:805-810

6. Martí MJ, Tolosa E, Campdelacreu J (2003) Clinical overview of the synucleinopathies. Mov Disord 18(Suppl 6):S21-S27

7. Villar-Piqué A, Lopes da Fonseca T, Sant'Anna R, Szegö ÉM, Fonseca-Ornelas L et al (2016) Environmental and genetic factors support the dissociation between alpha-synuclein aggregation and toxicity. Proc Natl Acad Sci USA 113:E6506-E6515

8. Ferreon AC, Gambin Y, Lemke EA, Deniz AA (2009) Interplay of alpha-synuclein binding and conformational switching probed by single-molecule fluorescence. Proc Natl Acad Sci USA 106:5645-5650

9. Frimpong AK, Abzalimov RR, Uversky VN, Kaltashov IA (2010) Characterization of intrinsically disordered proteins with electrospray ionization mass spectrometry: conformational heterogeneity of alpha-synuclein. Protein 78:714-722

10. Bridi JC, Hirth F (2018) Mechanisms of $\alpha$-synuclein induced synaptopathy in Parkinson's disease. Front Neurosci 12:80

11. Cascella R, Chen SW, Bigi A, Camino JD, Xu CK et al (2021) The release of toxic oligomers from alpha-synuclein fibrils induces dysfunction in neuronal cells. Nat Commun 12:1814

12. Cremades N, Cohen SI, Deas E, Abramov AY, Chen AY et al (2012) Direct observation of the interconversion of normal and toxic forms of alpha-synuclein. Cell 149:1048-1059

13. Hansen C, Angot E, Bergström AL, Steiner JA, Pieri L et al (2011) $\alpha$-Synuclein propagates from mouse brain to grafted dopaminergic neurons and seeds aggregation in cultured human cells. J Clin Invest 121:715-725

14. Luk KC, Song C, O'Brien P, Stieber A, Branch JR et al (2009) Exogenous alpha-synuclein fibrils seed the formation of Lewy body-like intracellular inclusions in cultured cells. Proc Natl Acad Sci USA 106:20051-20056

15. Luk KC, Kehm V, Carroll J, Zhang B, O'Brien P et al (2012) Pathological $\alpha$-synuclein transmission initiates Parkinsonlike neurodegeneration in nontransgenic mice. Science 338:949-953

16. Rey NL, Petit GH, Bousset L, Melki R, Brundin P (2013) Transfer of human $\alpha$-synuclein from the olfactory bulb to interconnected brain regions in mice. Acta Neuropathol 126:555-573

17. Volpicelli-Daley LA, Luk KC, Patel TP, Tanik SA, Riddle DM et al (2011) Exogenous $\alpha$-synuclein fibrils induce Lewy body pathology leading to synaptic dysfunction and neuron death. Neuron 72:57-71

18. Bartels T, Choi JG, Selkoe DJ (2011) $\alpha$-Synuclein occurs physiologically as a helically folded tetramer that resists aggregation. Nature 477:107-110

19. Burré J, Vivona S, Diao J, Sharma M, Brunger AT, Südhof TC (2013) Properties of native brain $\alpha$-synuclein. Nature 498:E4-6 (Discussion E6-7)

20. Burré J, Sharma M, Tsetsenis T, Buchman V, Etherton MR, Südhof TC (2010) Alpha-synuclein promotes SNARE-complex assembly in vivo and in vitro. Science 329:1663-1667

21. Fagerqvist T, Lindström V, Nordström E, Lord A, Tucker SM et al (2013) Monoclonal antibodies selective for $\alpha$-synuclein oligomers/protofibrils recognize brain pathology in Lewy body disorders and $\alpha$-synuclein transgenic mice with the diseasecausing A30P mutation. J Neurochem 126:131-144

22. Kayed R, Head E, Thompson JL, McIntire TM, Milton SC, Cotman CW, Glabe CG (2003) Common structure of soluble amyloid oligomers implies common mechanism of pathogenesis. Science 300:486-489
23. Lassen LB, Gregersen E, Isager AK, Betzer C, Kofoed RH et al (2018) ELISA method to detect $\alpha$-synuclein oligomers in cell and animal models. PLoS ONE 13:e0196056

24. Kumar ST, Jagannath S, Francois C, Vanderstichele H, Stoops E, Lashuel HA (2020) How specific are the conformationspecific $\alpha$-synuclein antibodies? Characterization and validation of $16 \alpha$-synuclein conformation-specific antibodies using well-characterized preparations of $\alpha$-synuclein monomers, fibrils and oligomers with distinct structures and morphology. Neurobiol Dis 146:105086

25. Yoshiike Y, Minai R, Matsuo Y, Chen Y-R, Kimura T, Takashima A (2008) Amyloid oligomer conformation in a group of natively folded proteins. PLoS ONE 3:e3235

26. Kramer ML, Schulz-Schaeffer WJ (2007) Presynaptic alphasynuclein aggregates, not Lewy bodies, cause neurodegeneration in dementia with Lewy bodies. J Neurosci 27:1405-1410

27. Roberts RF, Wade-Martins R, Alegre-Abarrategui J (2015) Direct visualization of alpha-synuclein oligomers reveals previously undetected pathology in Parkinson's disease brain. Brain 138(Pt 6):1642-1657

28. Outeiro TF, Putcha P, Tetzlaff JE, Spoelgen R, Koker M, Carvalho F, Hyman BT, McLean PJ (2008) Formation of toxic oligomeric alpha-synuclein species in living cells. PLoS ONE 3:1-9

29. Dimant H, Kalia SK, Kalia LV, Zhu LN, Kibuuka L et al (2013) Direct detection of alpha synuclein oligomers in vivo. Acta Neuropathol Commun 1:6

30. Cremades N, Chen SW, Dobson CM (2017) Structural characteristics of $\alpha$-synuclein oligomers. Int Rev Cell Mol Biol 329:79-143

31. Cohen SI, Vendruscolo M, Dobson CM, Knowles TPJ (2012) From macroscopic measurements to microscopic mechanisms of protein aggregation. J Mol Biol 421:160-171

32. Cohen SIA, Linse S, Luheshi LM, Hellstrand E, White DA et al (2013) Proliferation of amyloid- $\beta 42$ aggregates occurs through a secondary nucleation mechanism. Proc Natl Acad Sci USA 110:9758-9763

33. Ghosh D, Singh PK, Sahay S, Nath Jha N, Jacob RS et al (2015) Structure based aggregation studies reveal the presence of helix-rich intermediate during $\alpha$-Synuclein aggregation. Sci Rep 5:9228

34. Lashuel HA, Petre BM, Wall J, Simon M, Nowak RJ, Walz T, Lansbury PT Jr (2002) Alpha-synuclein, especially the Parkinson's disease-associated mutants, forms pore-like annular and tubular protofibrils. J Mol Biol 322:1089-1102

35. Arosio P, Knowles TPJ, Linse S (2015) On the lag phase in amyloid fibril formation. Phys Chem Chem Phys 17:7606-7618

36. Guerrero-Ferreira R, Kovacik L, Ni D, Stahlberg H (2020) New insights on the structure of alpha-synuclein fibrils using cryo-electron microscopy. Curr Opin Neurobiol 61:89-95

37. Camino JD, Gracia P, Cremades N (2021) The role of water in the primary nucleation of protein amyloid aggregation. Biophys Chem 269:106520

38. Bieschke J, Russ J, Friedrich RP, Ehrnhoefer DE, Wobst H et al (2010) EGCG remodels mature alpha-synuclein and amyloidbeta fibrils and reduces cellular toxicity. Proc Natl Acad Sci USA 107:7710-7715

39. Cappai R, Leck S-L, Tew DJ, Williamson NA, Smith DP et al (2005) Dopamine promotes alpha-synuclein aggregation into SDS-resistant soluble oligomers via a distinct folding pathway. FASEB J 19:1377-1379

40. Ehrnhoefer DE, Bieschke J, Boeddrich A, Herbst M, Masino L et al (2008) EGCG redirects amyloidogenic polypeptides into unstructured, offpathway oligomers. Nat Struct Mol Biol $15: 558-566$ 
41. Hong DP, Fink AL, Uversky VN (2009) Smoking and Parkinson's disease: does nicotine affect alpha-synuclein fibrillation? Biochim Biophys Acta 1794:282-290

42. Hong DP, Fink AL, Uversky VN (2008) Structural characteristics of alpha-synuclein oligomers stabilized by the flavonoid baicalein. J Mol Biol 383:214-223

43. Zhou W, Long C, Reaney SH, Di Monte DA, Fink AL, Uversky VN (2010) Methionine oxidation stabilizes non-toxic oligomers of alpha-synuclein through strengthening the auto-inhibitory intra-molecular long-range interactions. Biochim Biophys Acta 1802:322-330

44. Näsström T, Wahlberg T, Karlsson M, Nikolajeff F, Lannfelt L, Ingelsson M, Bergström J (2009) The lipid peroxidation metabolite 4-oxo-2-nonenal cross-links alpha-synuclein causing rapid formation of stable oligomers. Biochem Biophys Res Commun 378:872-876

45. Qin Z, Hu D, Han S, Reaney SH, Di Monte DA, Fink AL (2007) Effect of 4-hydroxy-2-nonenal modification on alphasynuclein aggregation. J Biol Chem 282:5862-5870

46. Castillo EJ, Koenig JL, Anderson JM, Lo J (1985) Protein adsorption on hydrogels. II. Reversible and irreversible interactions between lysozyme and soft contact lens surfaces. Biomaterials 6:338-345

47. Castillo EJ, Koenig JL, Anderson JM (1986) Characterization of protein adsorption on soft contact lenses. IV. Comparison of in vivo spoilage with the in vitro adsorption of tear proteins. Biomaterials 7:89-96

48. Griebenow K, Klibanov AM (1995) Lyophilization-induced reversible changes in the secondary structure of proteins. Proc Natl Acad Sci USA 92:10969-10976

49. Mukherjee S, Chowdhury P, Gai F (2009) Effect of dehydration on the aggregation kinetics of two amyloid peptides. J Phys Chem B 113:531-535

50. Prestrelski SJ, Tedeschi N, Arakawa T, Carpenter JF (1993) Dehydration-induced conformational transitions in proteins and their inhibition by stabilizers. Biophys J 65:661-671

51. Camino JD, Gracia P, Chen SW, Sot J, de la Arada I et al (2020) The extent of protein hydration dictates the preference for heterogeneous or homogeneous nucleation generating either parallel or antiparallel $\beta$-sheet $\alpha$-synuclein aggregates. Chem Sci 11:11902-11914

52. Celej MS, Sarroukh R, Goormaghtigh R, Fidelio GD, Ruysschaert J-M, Raussens V (2012) Toxic prefibrillar $\alpha$-synuclein amyloid oligomers adopt a distinctive antiparallel $\beta$-sheet structure. Biochem J 443:719-726

53. Cerf E, Sarroukh R, Tamamizu-Kato S, Breydo L, Derclaye S et al (2009) Antiparallel beta-sheet: a signature structure of the oligomeric amyloid beta-peptide. Biochem J 421:415-423

54. Chen SW, Drakulic S, Deas E, Ouberai M, Aprile FA et al (2015) Structural characterization of toxic oligomers that are kinetically trapped during $\alpha$-synuclein fibril formation. Proc Natl Acad Sci USA 112(16):E1994-2003

55. Zou Y, Li Y, Hao W, Hu X, Ma G (2013) Parallel $\beta$-sheet fibril and antiparallel $\beta$-sheet oligomer: new insights into amyloid formation of hen egg white lysozyme under heat and acidic condition from FTIR spectroscopy. J Phys Chem B 117:4003-4013

56. Santos J, Gracia P, Navarro S et al (2021) $\alpha$-Helical peptidic scaffolds to target $\alpha$-synuclein toxic species with nanomolar affinity. Nat Commun 12:3752

57. Froula JM, Castellana-Cruz M, Anabtawi NM, Camino JD, Chen SW et al (2019) Defining $\alpha$-synuclein species responsible for Parkinson's disease phenotypes in mice. J Biol Chem 294:10392-10406

58. Angelova PR, Ludtmann MH, Horrocks MH, Negoda A, Cremades $\mathrm{N}$ et al (2016) $\mathrm{Ca}^{2+}$ is a key factor in $\alpha$-synuclein-induced neurotoxicity. J Cell Sci 129:1792-1801
59. Deas E, Cremades N, Angelova PR, Ludtmann MH, Yao Z et al (2016) Alpha-synuclein oligomers interact with metal ions to induce oxidative stress and neuronal death in Parkinson's disease. Antiox Redox Signal 24:376-391

60. Giehm L, Svergun DI, Otzen DE, Vestergaard B (2011) Lowresolution structure of a vesicle disrupting $\alpha$-synuclein oligomer that accumulates during fibrillation. Proc Natl Acad Sci USA 108:3246-3251

61. Chen SW, Cremades N (2018) Preparation of $\alpha$-synuclein amyloid assemblies for toxicity experiments. Methods Mol Biol 1779:45-60

62. Gallea JI, Celej MS (2014) Structural insights into amyloid oligomers of the Parkinson disease-related protein $\alpha$-synuclein. J Biol Chem 289:26733-26742

63. Paslawski W, Mysling S, Thomsen K, Jørgensen TJD, Otzen DE (2014) Co-existence of two different $\alpha$-synuclein oligomers with different core structures determined by hydrogen/deuterium exchange mass spectrometry. Angew Chem Int Ed Engl 53:7560-7563

64. Fusco G, Chen SW, Williamson PTF, Cascella R, Perni M et al (2017) Structural basis of membrane disruption and cellular toxicity by $\alpha$-synuclein oligomers. Science 358:1440-1443

65. Smith JF, Knowles TPJ, Dobson CM, Macphee CE, Welland ME (2006) Characterization of the nanoscale properties of individual amyloid fibrils. Proc Natl Acad Sci USA 103:15806-15811

66. Kahle PJ, Neumann M, Ozmen L, Müller V, Odoy S et al (2001) Selective insolubility of alpha-synuclein in human LBs diseases is recapitulated in a transgenic mouse model. Am J Pathol 159:2215-2225

67. Periquet M, Fulga T, Myllykangas L, Schlossmacher MG, Feany MB (2007) Aggregated alpha-synuclein mediates dopaminergic neurotoxicity in vivo. J Neurosci 27:3338-3346

68. Danzer KM, Haasen D, Karow AR, Moussaud S, Habeck M et al (2007) Different species of alpha-synuclein oligomers induce calcium influx and seeding. J Neurosci 27:9220-9232

69. Vivoli Vega M, Cascella R, Chen SW, Fusco G, De Simone A et al (2019) The toxicity of misfolded protein oligomers is independent of their secondary structure. ACS Chem Biol $14: 1593-1600$

70. Volles MJ, Lee SJ, Rochet JC, Shtilerman MD, Ding TT, Kessler JC, Lansbury PT Jr (2001) Vesicle permeabilization by protofibrillar alpha-synuclein: implications for the pathogenesis and treatment of Parkinson's disease. Biochemistry 40:7812-7819

71. Luth ES, Stavrovskaya IG, Bartels T, Kristal BS, Selkoe DJ (2014) Soluble, prefibrillar $\alpha$-synuclein oligomers promote complex I-dependent, $\mathrm{Ca}^{2+}$-induced mitochondrial dysfunction. J Biol Chem 289:21490-21507

72. Ludtmann MHR, Angelova PR, Horrocks MH, Choi ML, Rodrigues $M$ et al (2018) $\alpha$-Synuclein oligomers interact with ATP synthase and open the permeability transition pore in Parkinson's disease. Nat Commun 9:2293

73. Chinta SJ, Mallajosyula JK, Rane A, Andersen JK (2010) Mitochondrial $\alpha$-synuclein accumulation impairs complex I function in dopaminergic neurons and results in increased mitophagy in vivo. Neurosci Lett 486:235-239

74. Lindström V, Gustafsson G, Sanders LH, Howlett EH, Sigvardson J et al (2017) Extensive uptake of $\alpha$-synuclein oligomers in astrocytes results in sustained intracellular deposits and mitochondrial damage. Mol Cell Neurosci 82:143-156

75. Gustafsson G, Eriksson F, Möller C, da Fonseca TL, Outeiro $\mathrm{TF}$ et al (2017) Cellular Uptake of $\alpha$-Synuclein OligomerSelective Antibodies is Enhanced by the Extracellular Presence of $\alpha$-Synuclein and Mediated via Fc $\gamma$ Receptors. Cell Mol Neurobiol 37(1):121-131 
76. Lee HJ, Suk JE, Bae EJ, Lee JH, Paik SR, Lee SJ (2008) Assembly-dependent endocytosis and clearance of extracellular alpha-synuclein. Int J Biochem Cell Biol 40:1835-1849

77. Colla E, Coune P, Liu Y, Pletnikova O, Troncoso JC, Iwatsubo T, Schneider BL, Lee MK (2012) Endoplasmic reticulum stress is important for the manifestations of $\alpha$-synucleinopathy in vivo. J Neurosci 32:3306-3320

78. Jiang P, Gan M, Ebrahim AS, Lin WL, Melrose HL, Yen SH (2010) ER stress response plays an important role in aggregation of $\alpha$-synuclein. Mol Neurodegener 5:56

79. Emmanouilidou E, Melachroinou K, Roumeliotis T, Garbis SD, Ntzouni M, Margaritis LH et al (2010) Cell-produced alpha-synuclein is secreted in a calcium-dependent manner by exosomes and impacts neuronal survival. J Neurosci 30:6838-6851

80. Lindersson E, Beedholm R, Højrup P, Moos T, Gai W, Hendil KB, Jensen PH (2004) Proteasomal inhibition by alpha-synuclein filaments and oligomers. J Biol Chem 279:12924-12934

81. Scudamore O, Ciossek T (2018) Increased oxidative stress exacerbates $\alpha$-synuclein aggregation in vivo. J Neuropathol Exp Neurol 77:443-453

82. Venda LL, Cragg SJ, Buchman VL, Wade-Martins R (2010) $\alpha$-Synuclein and dopamine at the crossroads of Parkinson's disease. Trends Neurosci 33(12):559-568

83. Hughes CD, Choi ML, Ryten M, Hopkins L, Drews A et al (2019) Picomolar concentrations of oligomeric alpha-synuclein sensitizes TLR4 to play an initiating role in Parkinson's disease pathogenesis. Acta Neuropathol 137:103-120

84. Kim C, Ho DH, Suk JE, You S, Michael S et al (2013) Neuronreleased oligomeric $\alpha$-synuclein is an endogenous agonist of TLR2 for paracrine activation of microglia. Nat Commun 4:1562

85. Prots I, Grosch J, Brazdis RM, Simmnacher K, Veber V et al (2018) $\alpha$-Synuclein oligomers induce early axonal dysfunction in human iPSC-based models of synucleinopathies. Proc Natl Acad Sci USA 115:7813-7818

86. Kaufmann TJ, Harrison PM, Richardson MJ, Pinheiro TJ, Wall MJ (2016) Intracellular soluble $\alpha$-synuclein oligomers reduce pyramidal cell excitability. J Physiol 594:2751-2772

87. Rockenstein E, Nuber S, Overk CR, Ubhi K, Mante M et al (2014) Accumulation of oligomer-prone $\alpha$-synuclein exacerbates synaptic and neuronal degeneration in vivo. Brain 137(Pt 5):1496-1513

88. Durante V, de Iure A, Loffredo V, Vaikath N, De Risi M et al (2019) Alpha-synuclein targets GluN2A NMDA receptor subunit causing striatal synaptic dysfunction and visuospatial memory alteration. Brain 142:1365-1385

89. Ferreira DG, Temido-Ferreira M, Vicente Miranda H, Batalha VL et al (2017) $\alpha$-synuclein interacts with PrPC to induce cognitive impairment through mGluR5 and NMDAR2B. Nat Neurosci 20:1569-1579

90. Campioni S, Mannini B, Zampagni M, Pensalfini A, Parrini C et al (2010) A causative link between the structure of aberrant protein oligomers and their toxicity. Nat Chem Biol 6:140-147

91. Mannini B, Mulvihill E, Sgromo C, Cascella R, Khodarahmi $\mathrm{R}$ et al (2014) Toxicity of protein oligomers is rationalized by a function combining size and surface hydrophobicity. ACS Chem Biol 9:2309-2317

92. Cascella R, Perni M, Chen SW, Fusco G, Cecchi C et al (2019) Probing the origin of the toxicity of oligomeric aggregates of $\alpha$-synuclein with antibodies. ACS Chem Biol 14:1352-1362

93. Limbocker R, Mannini B, Ruggeri FS, Cascella R, Xu CK et al (2020) Trodusquemine displaces protein misfolded oligomers from cell membranes and abrogates their cytotoxicity through a generic mechanism. Commun Biol 3:435

94. Limbocker R, Staats R, Chia S, Ruggeri FS, Mannini B et al (2021) Squalamine and its derivatives modulate the aggregation of amyloid- $\beta$ and $\alpha$-synuclein and suppress the toxicity of their oligomers. Front Neurosci 15:680026

95. Perni M, Galvagnion C, Maltsev A, Meisl G, Müller MB et al (2017) A natural product inhibits the initiation of $\alpha$-synuclein aggregation and suppresses its toxicity. Proc Natl Acad Sci USA 114:E1009-E1017

96. Wrasidlo W, Tsigelny IF, Price DL, Dutta G, Rockenstein E et al (2016) A de novo compound targeting $\alpha$-synuclein improves deficits in models of Parkinson's disease. Brain 139(Pt 12):3217-3236

97. Ysselstein D, Dehay B, Costantino IM, McCabe GP, Frosch MP et al (2017) Endosulfine-alpha inhibits membrane-induced $\alpha$-synuclein aggregation and protects against $\alpha$-synuclein neurotoxicity. Acta Neuropathol Commun 5:3

98. Lindström V, Fagerqvist T, Nordström E, Eriksson F, Lord A et al (2014) Immunotherapy targeting $\alpha$-synuclein protofibrils reduced pathology in (Thy-1)-h[A30P] $\alpha$-synuclein mice. Neurobiol Dis 69:134-143

99. Spencer B, Williams S, Rockenstein E, Valera E, Xin W et al (2016) $\alpha$-synuclein conformational antibodies fused to penetratin are effective in models of Lewy body disease. Ann Clin Transl Neurol 3:588-606

100. Aasly JO, Johansen KK, Brønstad G, Warø BJ, Majbour NK et al (2014) Elevated levels of cerebrospinal fluid $\alpha$-synuclein oligomers in healthy asymptomatic LRRK2 mutation carriers. Front Aging Neurosci 6:248

101. Paleologou KE, Kragh CL, Mann DM, Salem SA, Al-Shami R et al (2009) Detection of elevated levels of soluble alpha-synuclein oligomers in post-mortem brain extracts from patients with dementia with Lewy bodies. Brain 132(Pt 4):1093-1101

102. Park MJ, Cheon SM, Bae HR, Kim SH, Kim JW (2011) Elevated levels of $\alpha$-synuclein oligomer in the cerebrospinal fluid of drugnaïve patients with Parkinson's disease. J Clin Neurol 7:215-222

103. Parnetti L, Chiasserini D, Persichetti E, Eusebi P, Varghese S et al (2014) Cerebrospinal fluid lysosomal enzymes and alphasynuclein in Parkinson's disease. Mov Disord 29:1019-1027

104. Sharon R, Bar-Joseph I, Frosch MP, Walsh DM, Hamilton JA, Selkoe DJ (2003) The formation of highly soluble oligomers of alpha-synuclein is regulated by fatty acids and enhanced in Parkinson's disease. Neuron 37:583-595

105. Tokuda T, Salem SA, Allsop D et al (2006) Decreased $\alpha$-synuclein in cerebrospinal fluid of aged individuals and subjects with Parkinson's disease. Biochem Biophys Res Commun 349:162-166

106. Shahnawaz M, Mukherjee A, Pritzkow S et al (2020) Discriminating $\alpha$-synuclein strains in Parkinson's disease and multiple system atrophy. Nature 578:273-277

107. Arima K, Ueda K, Sunohara N, Hirai S, Izumiyama Y et al (1998) Immunoelectron-microscopic demonstration of NACP/ $\alpha$ synuclein-epitopes on the filamentous component of Lewy bodies in Parkinson's disease and in dementia with Lewy bodies. Brain Res 808:93-100

108. Goedert M, Jakes R, Spillantini MG (2017) The synucleinopathies: twenty years on. J Parkinsons Dis 7(s1):S51-S69

109. Lashuel HA, Overk CR, Oueslati A, Masliah E (2013) The many faces of $\alpha$-synuclein: from structure and toxicity to therapeutic target. Nature Rev Neurosci 14:38-48

110. McKeith IG, Boeve BF, Dickson DW, Halliday G, Taylor JP et al (2017) Diagnosis and management of dementia with Lewy bodies: fourth consensus report of the DLB Consortium. Neurology 89:88-100

111. Spillantini MG, Crowther RA, Jakes R, Hasegawa M, Goedert M (1998) Alpha-synuclein in filamentous inclusions of Lewy bodies from Parkinson's disease and dementia with lewy bodies. Proc Natl Acad Sci USA 95:6469-6473 
112. Crowther RA, Daniel SE, Goedert M (2000) Characterisation of isolated alpha-synuclein filaments from substantia nigra of Parkinson's disease brain. Neurosci Lett 292(2):128-130

113. Miake H, Mizusawa H, Iwatsubo T, Hasegawa M (2002) Biochemical characterization of the core structure of $\alpha$-synuclein filaments. J Biol Chem 277:19213-19219

114. Vilar M, Chou HT, Lührs T, Maji SK, Riek-Loher D et al (2008) The fold of alpha-synuclein fibrils. Proc Natl Acad Sci USA 105:8637-8642

115. Chen M, Margittai M, Chen J, Langen R (2007) Investigation of alpha-synuclein fibril structure by site-directed spin labeling. J Biol Chem 282(34):24970-24979

116. Comellas G, Lemkau LR, Nieuwkoop AJ, Kloepper KD, Ladror DT et al (2011) Structured regions of $\alpha$-synuclein fibrils include the early-onset Parkinson's disease mutation sites. J Mol Biol 411(4):881-895

117. Guilliams T, El-Turk F, Buell AK, O'Day EM, Aprile FA et al (2013) Nanobodies raised against monomeric $\alpha$-synuclein distinguish between fibrils at different maturation stages. J Mol Biol 425(14):2397-2411

118. Alam P, Bousset L, Melki R, Otzen DE (2019) Alpha-synuclein oligomers and fibrils: a spectrum of species, a spectrum of toxicities. J Neurochem 150:522-534

119. Tuttle MD, Comellas G, Nieuwkoop AJ, Covell DJ, Berthold DA et al (2016) Solid-state NMR structure of a pathogenic fibril of full-length human $\alpha$-synuclein. Nat Struct Mol Biol 23(5):409-415

120. Giasson BI, Murray IV, Trojanowski JQ, Lee VM (2001) A hydrophobic stretch of 12 amino acid residues in the middle of alpha-synuclein is essential for filament assembly. J Biol Chem 276(4):2380-2386

121. Schweighauser M, Shi Y, Tarutani A et al (2020) Structures of $\alpha$-synuclein filaments from multiple system atrophy. Nature 585:464-469

122. Rodriguez JA, Ivanova MI, Sawaya MR, Cascio D, Reyes FE et al (2015) Structure of the toxic core of $\alpha$-synuclein from invisible crystals. Nature 525:486-490

123. Bousset L, Pieri L, Ruiz-Arlandis G et al (2013) Structural and functional characterization of two alpha-synuclein strains. Nat Commun 4:1-13

124. Peelaerts W, Bousset L, Van der Perren A, Moskalyuk A, Pulizzi R, Giugliano M, Van den Haute C, Melki R, Baekelandt V (2015) $\alpha$-Synuclein strains cause distinct synucleinopathies after local and systemic administration. Nature 522:340-344

125. Peng C, Gathagan RJ, Covell DJ, Medellin C, Stieber A et al (2018) Cellular milieu imparts distinct pathological $\alpha$-synuclein strains in $\alpha$-synucleinopathies. Nature 557:558-563

126. Brehme M, Voisine C, Rolland T, Wachi S, Soper JH et al (2014) A chaperone subnetwork safeguards proteostasis in aging and neurodegenerative disease. Cell Rep 9:1135-1150

127. Morimoto RI (2011) The heat shock response: systems biology of proteotoxic stress in aging and disease. Cold Spring Harb Symp Quant Biol 76:91-99

128. Krüger R, Kuhn W, Müller T, Woitalla D, Graeber M et al (1998) Ala30Pro mutation in the gene encoding alpha-synuclein in Parkinson's disease. Nat Genet 18:106-108

129. Polymeropoulos MH, Lavedan C, Leroy E, Ide SE, Dehejia A et al (1997) Mutation in the alpha-synuclein gene identified in families with Parkinson's disease. Science 276:2045-2047

130. Proukakis C, Houlden H, Schapira AH (2013) Somatic alphasynuclein mutations in Parkinson's disease: hypothesis and preliminary data. Mov Disord 28:705-712

131. Singleton AB, Farrer M, Johnson J, Singleton A, Hague $S$ et al (2003) Alpha-Synuclein locus triplication causes Parkinson's disease. Science 302:841
132. Zarranz JJ, Alegre J, Gómez-Esteban JC, Lezcano E, Ros R et al (2004) The new mutation, E46K, of alpha-synuclein causes Parkinson and Lewy body dementia. Ann Neurol 55:164-173

133. Conway KA, Lee SJ, Rochet JC, Ding TT, Williamson RE, Lansbury PT Jr (2000) Acceleration of oligomerization, not fibrillization, is a shared property of both alpha-synuclein mutations linked to early-onset Parkinson's disease: implications for pathogenesis and therapy. Proc Natl Acad Sci USA 97:571-576

134. Shahmoradian SH, Lewis AJ, Genoud C, Hench J, Moors TE et al (2019) Lewy pathology in Parkinson's disease consists of crowded organelles and lipid membranes. Nat Neurosci 22:1099-1109

135. Mahul-Mellier A-L, Burtscher J, Maharjan N, Weerens L, Croisier $\mathrm{M}$ et al (2020) The process of Lewy body formation, rather than simply $\alpha$-synuclein fibrillization, is one of the major drivers of neurodegeneration. Proc Natl Acad Sci USA 117:4971-4982

136. Ham S, Yun SP, Kim H, Kim D, Seo BA et al (2020) Amyloid-like oligomerization of AIMP2 contributes to alphasynuclein interaction and Lewy-like inclusion. Sci Transl Med 12(569):eaax0091

137. Petrucci S, Ginevrino M, Valente EM (2016) Phenotypic spectrum of a-synuclein mutations: new insights from patients and cellular models. Parkinsonism Relat Disord 22:S16-S20

138. Satake W, Nakabayashi Y, Mizuta I, Hirota Y, Ito C et al (2009) Genome- wide association study identifies common variants at four loci as genetic risk factors for Parkinson's disease. Nat Genet 41:1303-1307

139. Simón-Sánchez J, Schulte C, Bras JM, Sharma M, Gibbs JR et al (2009) Genomewide association study reveals genetic risk underlying Parkinson's disease. Nat Genet 41:1308-1312

140. Eusebi P, Giannandrea D, Biscetti L, Abraha I, Chiasserini D, Orso M, Calabresi P, Parnetti L (2017) Diagnostic utility of cerebrospinal fluid a-synuclein in Parkinson's disease: a systematic review and meta-analysis. Mov Disord 32:1389-1400

141. Fairfoul G, McGuire LI, Pal S, Ironside JW, Neumann J et al (2016) a-Synuclein RT-QuIC in the CSF of patients with a-synucleinopathies. Ann Clin Transl Neurol 3:812-818

142. Groveman BR, Orrù CD, Hughson AG, Raymond LD, Zanusso $\mathrm{G}$ et al (2018) Rapid and ultra-sensitive quantitation of diseaseassociated a-synuclein seeds in brain and cerebrospinal fluid by aSyn RT-QuIC. Acta Neuropathol Commun 6:7

143. Masuda-Suzukake M, Nonaka T, Hosokawa M, Oikawa T et al (2013) Prion-like spreading of pathological $\alpha$-synuclein in brain. Brain 136:1128-1138

144. Paumier KL, Luk KC, Manfredsson FP, Kanaan NM, Lipton JW et al (2015) Intrastriatal injection of pre-formed mouse a-synuclein fibrils into rats triggers a-synuclein pathology and bilateral nigrostriatal degeneration. Neurobiol Dis 82:185-199

145. Recasens A, Dehay B, Bové J, Carballo-Carbajal I, Dovero S et al (2014) Lewy body extracts from Parkinson disease brains trigger $\alpha$-synuclein pathology and neurodegeneration in mice and monkeys. Ann Neurol 75:351-362

146. Sacino AN, Brooks M, Thomas MA, McKinney AB, Lee $S$ et al (2014) Intramuscular injection of $\alpha$-synuclein induces CNS $\alpha$-synuclein pathology and a rapid-onset motor phenotype in transgenic mice. Proc Natl Acad Sci USA 111:10732-10737

147. Kordower JH, Chu Y, Hauser RA, Freeman TB, Olanow CW (2008) Lewy body-like pathology in long-term embryonic nigral transplants in Parkinson's disease. Nat Med 14:504-506

148. Li J-Y, Englund E, Holton JL, Soulet D, Hagell P et al (2008) Lewy bodies in grafted neurons in subjects with Parkinson's disease suggest host-to-graft disease propagation. Nat Med 14:501-503

149. Abdelmotilib H, Maltbie T, Delic V, Liu Z, Hu X et al (2017) a-Synuclein fibril-induced inclusion spread in rats and mice correlates with dopaminergic neurodegeneration. Neurobiol Dis 105:84-98 
150. Pieri L, Madiona K, Bousset L, Melki R (2012) Fibrillar alphasynuclein and huntingtin exon 1 assemblies are toxic to the cells. Biophys J 102:2894-2905

151. Pemberton S, Madiona K, Pieri L, Kabani M, Bousset L, Melki R (2011) Hsc70 protein interaction with soluble and fibrillar alphasynuclein. J Biol Chem 286:34690-34699

152. Flavin WP, Bousset L, Green ZC, Chu Y, Skarpathiotis S et al (2017) Endocytic vesicle rupture is a conserved mechanism of cellular invasion by amyloid proteins. Acta Neuropathol 134:629-653

153. Gustot A, Gallea JI, Sarroukh R, Celej MS, Ruysschaert J-M, Raussens V (2015) Amyloid fibrils are the molecular trigger of inflammation in Parkinson's disease. Biochem J 471:323-333

154. Hoffmann A, Ettle B, Bruno A, Kulinich A, Hoffmann A-C, von Wittgenstein J, Winkler J, Xiang W, Schlachetzki JCM (2016) Alpha-synuclein activates BV2 microglia dependent on its aggregation state. Biochem Biophys Res Comm 479:881-886

155. Peralta Ramos JM, Iribarren P, Bousset L, Melki R, Baekelandt V, Van der Perren A (2019) Peripheral inflammation regulates CNS immune surveillance through the recruitment of inflammatory monocytes upon systemic alpha-synuclein administration. Front Immunol 10:80

156. Chou TW, Chang NP, Krishnagiri M, Patel AP, Lindman M et al (2021) Fibrillar $\alpha$-synuclein induces neurotoxic astrocyte activation via RIP kinase signaling and NF- $\mathrm{KB}$. Cell Death Dis 12:756

157. Bigi A, Ermini E, Chen SW, Cascella R, Cecchi C (2021) Exploring the release of toxic oligomers from $\alpha$-synuclein fibrils with antibodies and STED microscopy. Life 11:431

158. Skamris T, Marasini C, Madsen KL, Foderà V, Vestergaard B (2019) Early stage alpha-synuclein amyloid fibrils are reservoirs of membrane-binding species. Sci Rep 9:1733

159. Martins IC, Kuperstein I, Wilkinson H, Maes E, Vanbrabant M et al (2008) Lipids revert inert Abeta amyloid fibrils to neurotoxic protofibrils that affect learning in mice. EMBO J 27:224-233

160. Tipping KW, Karamanos TK, Jakhria T, Iadanza MG, Goodchild $\mathrm{SC}$ et al (2015) $\mathrm{pH}$-induced molecular shedding drives the formation of amyloid fibril-derived oligomers. Proc Natl Acad Sci USA 112:5691-5696

161. Koffie RM, Meyer-Luehmann M, Hashimoto T, Adams KW, Mielke ML et al (2009) Oligomeric amyloid beta associates with postsynaptic densities and correlates with excitatory synapse loss near senile plaques. Proc Natl Acad Sci USA 106:4012-4017

162. Brahic M, Bousset L, Bieri G, Melki R, Gitler AD (2016) Axonal transport and secretion of fibrillar forms of a-synuclein, $A \beta 42$ peptide and HTTExon 1. Acta Neuropathol 131:539-548

163. Desplats P, Lee HJ, Bae EJ, Patrick C, Rockenstein E, Crews L, Spencer B, Masliah E, Lee SJ (2009) Inclusion formation and neuronal cell death through neuron-to-neuron transmission of alpha-synuclein. Proc Natl Acad Sci USA 106:13010-13015

164. Prusiner SB, Woerman AL, Mordes DA, Watts JC, Rampersaud $R$ et al (2015) Evidence for $\alpha$-synuclein prions causing multiple system atrophy in humans with Parkinsonism. Proc Natl Acad Sci USA 112:E5308-E5317

165. Prusiner SB (1982) Novel proteinaceous infectious particles cause scrapie. Science 216:136-144

166. Prusiner SB (1991) Molecular biology of prion diseases. Science 252:1515-1522

167. Clavaguera F, Bolmont T, Crowther RA, Abramowski D, Frank $S$ et al (2009) Transmission and spreading of tauopathy in transgenic mouse brain. Nat Cell Biol 11:909-913

168. Ruiz-Riquelme A, Lau HHC, Stuart E et al (2018) Prion-like propagation of $\beta$-amyloid aggregates in the absence of APP overexpression. Acta Neuropathol Commun 6:26

169. Ren PH, Lauckner J, Kachirskaia I et al (2009) Cytoplasmic penetration and persistent infection of mammalian cells by polyglutamine aggregates. Nat Cell Biol 11:219-225
170. Adler CH, Beach TG (2016) Neuropathological basis of nonmotor manifestations of Parkinson's disease. Mov Disord 31:1114-1119

171. Beach TG, Adler CH, Lue L, Sue LI, Bachalakuri J et al (2009) Unified staging system for Lewy body disorders: correlation with nigrostriatal degeneration, cognitive impairment and motor dysfunction. Acta Neuropathol 117:613-634

172. Braak H, Del Tredici K, Rüb U, de Vos RA, Steur ENJ et al (2003) Staging of brain pathology related to sporadic Parkinson's disease. Neurobiol Aging 24:197-211

173. Braak H, Rüb U, Gai WP, Del Tredici K (2003) Idiopathic Parkinson's disease: possible routes by which vulnerable neuronal types may be subject to neuroinvasion by an unknown pathogen. J Neural Transm 110:517-536

174. Braak H, Del Tredici K, Bratzke H, Hamm-Clement J, Sandmann-Keil D et al (2002) Staging of the intracerebral inclusion body pathology associated with idiopathic Parkinson's disease (preclinical and clinical stages). J Neurol 249(Suppl 3):1-5

175. Halliday G, Lees A, Stern M (2011) Milestones in Parkinson's disease-clinical and pathologic features. Mov Disord 26:1015-1021

176. Rietdijk CD, Perez-Pardo P, Garssen J, van Wezel RJ, Kraneveld AD (2017) Exploring Braak's hypothesis of Parkinson's disease. Front Neurol 8:37

177. El-Agnaf OM, Salem SA, Paleologou KE, Cooper LJ, Fullwood NJ et al (2003) $\alpha$-Synuclein implicated in Parkinson's disease is present in extracellular biological fluids, including human plasma. FASEB J 17:1945-1947

178. Devic I, Hwang H, Edgar JS et al (2011) Salivary $\alpha$-synuclein and DJ-1: potential biomarkers for Parkinson's disease. Brain 134:e178

179. Steiner JA, Quansah E, Brundin P (2018) The concept of alphasynuclein as a prion-like protein: ten years after. Cell Tissue Res 373:161-173

180. Danzer KM, Krebs SK, Wolff M, Birk G, Hengerer B (2009) Seeding induced by alpha-synuclein oligomers provides evidence for spreading of alpha-synuclein pathology. J Neurochem 111:192-203

181. Henderson MX, Cornblath EJ, Darwich A, Zhang B, Brown $H$ et al (2019) Spread of $\alpha$-synuclein pathology through the brain connectome is modulated by selective vulnerability and predicted by network analysis. Nat Neurosci 22:1248-1257

182. Lau A, So RWL, Lau HHC, Sang JC, Ruiz-Riquelme A et al (2020) $\alpha$-Synuclein strains target distinct brain regions and cell types. Nat Neurosci 23:21-31

183. Lövestam S, Schweighauser M, Matsubara T, Murayama S, Tomita $T$ et al (2021) Seeded assembly in vitro does not replicate the structures of $\alpha$-synuclein filaments from multiple system atrophy. FEBS Open Biol 11:999-1013

184. Lee HJ, Patel S, Lee SJ (2005) Intravesicular localization and exocytosis of alpha-synuclein and its aggregates. J Neurosci 25:6016-6024

185. Lee JG, Takahama S, Zhang G, Tomarev SI, Ye Y (2016) Unconventional secretion of misfolded proteins promotes adaptation to proteasome dysfunction in mammalian cells. Nat Cell Biol 18:765-776

186. Fontaine SN, Zheng D, Sabbagh JJ, Martin MD, Chaput D et al (2016) DnaJ/Hsc70 chaperone complexes control the extracellular release of neurodegenerative-associated proteins. EMBO J 35:1537-1549

187. Taylor AM, Blurton-Jones M, Rhee SW, Cribbs DH, Cotman CW, Jeon NL (2005) A microfluidic culture platform for CNS axonal injury, regeneration and transport. Nat Methods 2:599-605

188. Freundt EC, Maynard N, Clancy EK et al (2012) Neuron-toneuron transmission of alpha-synuclein fibrils through axonal transport. Ann Neurol 72:517-524 
189. Ulusoy A, Musgrove RE, Rusconi R, Klinkenberg M, Helwig $\mathrm{M}$ et al (2015) Neuron-to-neuron $\alpha$-synuclein propagation in vivo is independent of neuronal injury. Acta Neuropathol Commun 3:13

190. Mao X, Ou MT, Karuppagounder SS, Kam TI, Yin X et al (2016) Pathological $\alpha$ - synuclein transmission initiated by binding lymphocyte-activation gene 3. Science 353:6307

191. Tran HT, Chung CH, Iba M, Zhang B, Trojanowski JQ, Luk KC, Lee VM (2014) A-synuclein immunotherapy blocks uptake and templated propagation of misfolded $\alpha$-synuclein and neurodegeneration. Cell Rep 7:2054-2065

192. Rustom A, Saffrich R, Markovic I, Walther P, Gerdes HH (2004) Nanotubular highways for intercellular organelle transport. Science 303:1007-1010

193. Abounit S, Bousset L, Loria F, Zhu S, Chaumont F, Pieri L et al (2016) Tunneling nanotubes spread fibrillar $\alpha$-synuclein by intercellular trafficking of lysosomes. EMBO J 35:2120-2138

194. Bae EJ, Yang NY, Song M et al (2014) Glucocerebrosidase depletion enhances cell-to-cell transmission of $\alpha$-synuclein. Nat Commun 5:4755

195. Dilsizoglu SA, Samarani M, Syan S, Guardia CM, Nonaka T et al (2021) $\alpha$-Synuclein fibrils subvert lysosome structure and function for the propagation of protein misfolding between cells through tunneling nanotubes. PLoS 19:e3001287

196. Dieriks BV, Park TI-H, Fourie C, Faull RLM, Dragunow M, Curtis MA (2017) $\alpha$-Synuclein transfer through tunneling nanotubes occurs in SH-SY5Y cells and primary brain pericytes from Parkinson's disease patients. Sci Rep 7:42984

197. Gousset K, Schiff E, Langevin C, Marijanovic Z, Caputo A et al (2009) Prions hijack tunnelling nanotubes for intercellular spread. Nat Cell Biol 11:328-336

198. Victoria G, Arkhipenko A, Zhu S et al (2016) Astrocyte-to-neuron intercellular prion transfer is mediated by cell-cell contact. Sci Rep 6:20762

199. Chastagner P, Loria F, Vargas JY, Tois J, Diamond IM et al (2020) Fate and propagation of endogenously formed Tau aggregates in neuronal cells. EMBO Mol Med 12(12):e12025

200. Tardivel M, Bégard S, Bousset L et al (2016) Tunneling nanotube (TNT)-mediated neuron-to neuron transfer of pathological Tau protein assemblies. Acta Neuropathol Commun 4:117

201. Costanzo M, Abounit S, Marzo L, Danckaert A, Chamoun Z, Roux P, Zurzolo C (2013) Transfer of polyglutamine aggregates in neuronal cells occurs in tunneling nanotubes. J Cell Sci 126(Pt 16):3678-3685

202. Karpowicz RJ Jr, Haney CM, Mihaila TS, Sandler RM, Petersson EJ et al (2017) Selective imaging of internalized proteopathic $\alpha$-synuclein seeds in primary neurons reveals mechanistic insight into transmission of synucleinopathies. J Biol Chem 292:13482-13497

203. Nonaka T, Watanabe ST, Iwatsubo T, Hasegawa M (2010) Seeded aggregation and toxicity of $\{$ alpha $\}$-synuclein and tau: cellular models of neurodegenerative diseases. J Biol Chem 285:34885-34898

204. Hijaz BA, Volpicelli-Daley LA (2020) Initiation and propagation of $\alpha$-synuclein aggregation in the nervous system. Mol Neurodegener 15:19

205. Sacino AN, Brooks MM, Chakrabarty P, Saha K, Khoshbouei H, Golde TE, Giasson BI (2017) Proteolysis of $\alpha$-synuclein fibrils in the lysosomal pathway limits induction of inclusion pathology. $\mathrm{J}$ Neurochem 140:662-678

206. Zhang S, Liu YQ, Jia C, Lim YJ, Feng G et al (2021) Mechanistic basis for receptor-mediated pathological $\alpha$-synuclein fibril cellto-cell transmission in Parkinson's disease. Proc Natl Acad Sci USA 118:e2011196118
207. Holmes BB, DeVos SL, Kfoury N, Li M, Jacks R et al (2013) Heparan sulfate proteoglycans mediate internalization and propagation of specific proteopathic seeds. Proc Natl Acad Sci USA 110:E3138-E3147

208. Hudák A, Kusz E, Domonkos I, Jósvay K, Kodamullil AT et al (2019) Contribution of syndecans to cellular uptake and fibrillation of $\alpha$-synuclein and tau. Sci Rep 9:16543

209. Stopschinski BE, Holmes BB, Miller GM, Manon VA, VaquerAlicea J et al (2018) Specific glycosaminoglycan chain length and sulfation patterns are required for cell uptake of tau versus alpha-synuclein and beta-amyloid aggregates. J Biol Chem 293:10826-10840

210. Ihse E, Yamakado H, van Wijk XM, Lawrence R, Esko JD, Masliah E (2017) Cellular internalization of alpha-synuclein aggregates by cell surface heparan sulfate depends on aggregate conformation and cell type. Sci Rep 7:9008

211. Shrivastava AN, Redeker V, Fritz N, Pieri L, Almeida LG et al (2015) alpha-synuclein assemblies sequester neuronal alpha3- $\mathrm{Na}^{+} / \mathrm{K}^{+}$-ATPase and impair $\mathrm{Na}^{+}$gradient. EMBO J 34:2408-2423

212. De Carvalho AP, Sweadner KJ, Penniston JT, Zaremba J, Liu $\mathrm{L}$ et al (2004) Mutations in the $\mathrm{Na}+\mathrm{K}+$-ATPase alpha3 gene ATP1A3 are associated with rapid-onset dystonia parkinsonism. Neuron 43:169-175

213. Choi YR, Cha SH, Kang SJ, Kim JB, Jou I et al (2018) Prion-like Propagation of $\alpha$ - synuclein is regulated by the Fc $\gamma$ RIIB-SHP-1/2 signaling pathway in neurons. Cell Rep 22:136-148

214. Choi YR, Kang SJ, Kim JM, Lee SJ, Jou I, Joe EH, Park SM (2015) Fc $\gamma$ RIIB mediates the inhibitory effect of aggregated $\alpha$-synuclein on microglial phagocytosis. Neurobiol Dis 83:90-99

215. Kam TI, Park H, Gwon Y et al (2016) Fc $\gamma$ RIIb-SHIP2 axis links A $\beta$ to tau pathology by disrupting phosphoinositide metabolism in Alzheimer's disease model. Elife 5:e18691

216. Aulić S, Masperone L, Narkiewicz J, Isopi E, Bistaffa E et al (2017) $\alpha$-synuclein amyloids hijack prion protein to gain cell entry, facilitate cell-to-cell spreading and block prion replication. Sci Rep 7:10050

217. De Cecco E, Celauro L, Vanni S et al (2020) The uptake of tau amyloid fibrils is facilitated by the cellular prion protein and hampers prion propagation in cultured cells. J Neurochem 155:577-591

218. Scialò C, Celauro L, Zattoni M, Tran TH, Bistaffa E, Moda F, Kammerer R, Buratti E, Legname G (2021) The cellular prion protein increases the uptake and toxicity of TDP-43 fibrils. Viruses 13:1625

219. Salazar SV, Strittmatter SM (2017) Cellular prion protein as a receptor for amyloid- $\beta$ oligomers in Alzheimer's disease. Biochem Biophys Res Commun 483:1143-1147

220. Loria F, Vargas JY, Bousset L, Syan S, Salles A et al (2017) $\alpha$-Synuclein transfer between neurons and astrocytes indicates that astrocytes play a role in degradation rather than in spreading. Acta Neuropathol 134:789-808

221. Wiethoff CM, Wodrich H, Gerace L, Nemerow GR (2005) Adenovirus protein VI mediates membrane disruption following capsid disassembly. J Virol 79:1992-2000

222. Volpicelli-Daley LA, Luk KC, Lee VM (2014) Addition of exogenous $\alpha$-synuclein preformed fibrils to primary neuronal cultures to seed recruitment of endogenous $\alpha$-synuclein to Lewy body and Lewy neurite-like aggregates. Nat Protoc 9:2135-2146

Publisher's Note Springer Nature remains neutral with regard to jurisdictional claims in published maps and institutional affiliations. 